Hafner A., Brunner M., Laabs J.

\title{
Archaeology of the Alpine space. Research on the foothills, valley systems and high mountain landscapes of the Alps
}

\section{INTRODUCTION}

The European Alps are a fascinating megalandscape in the centre of Europe (Fig. 1). While the surrounding foothills are characterised by gentle hills, the highest Alpine peaks reach heights of more than $4000 \mathrm{~m}$. Viewed from the foothills of the Alps, they appear to form a mighty barrier and for a considerable period the mountains were mainly seen as an obstacle to communication and exchange. This view was further supported by ancient and medieval records, which described the Alps as locus horribilis (Mathieu 2015). Travellers were still wary of the Alps in the early modern period. It was only after the Age of Enlightenment in the $18^{\text {th }}$ century that the perception of the Alps changed. Johann Wolfgang von Goethe spent a night at the hospice on the Gotthard Pass in November 1779 admiring the Urseren Valley, as can be seen from one of his letters from Switzerland: "Mir ist's unter allen Gegenden, die ich kenne, die liebste und interessanteste (It is the finest and most interesting of all landscapes I have known)".

We know from various archaeological studies that at least during the Holocene the Alps were not an obstacle to exchange and communication. Alpine hunters of the Mesolithic were the first to leave behind traces of their hunting camps in rock shelters high above the treeline. High-Alpine passes have yielded evidence of crossings since the early $5^{\text {th }}$ millennium BC and the famous Neolithic ice mummy from the Ötztal Alps was found at an altitude of over $3200 \mathrm{~m}$ a.s.l., making it probably the highest archaeological site in Europe. Several studies have been undertaken in recent years on multiple transalpine networks and vertical mobility (Borello et al. 2013; Hafner/Schwörer 2017). While the peripheral areas of the Alps experience high precipitation, the inner-Alpine dry zones in large valley systems are climatically the most favourable regions. Neolithic settlements, graves and ritual sites in areas such as the Rhône Valley in western Switzerland, the Aosta Valley in the Piedmont and the Vinschgau in South Tyrol in Italy clearly attest to the early human appropriation of landscapes
(Bätzing 2015, 44 and map 7). Until recently the foothills of the Alps were landscapes characterised by lakes and wetlands. The latter were largely drained in the $19^{\text {th }}$ century in order to gain arable land. Bogs and smaller lakes owe their existence to the last Würm glaciation. When the ice melted, small hollows, so-called kettle holes formed, thus creating ponds and marshy areas. Large bodies of water like Lakes Geneva and Constance north of the Alps or Lake Garda south of the Alps resulted from geologically old tectonic processes alternating with glacial erosion and deposition during the Würm glaciation period. Lakes and bogs are known for their rich archaeological heritage. Neolithic and Bronze Age settlements form by far the largest part of this heritage, but dugout canoes, fish weirs, pathways, bridges and other water-related structures have also come to light. Thanks to this vast array of geomorphological forms within a relatively small area, the Alps are one of the most diverse landscapes in Europe (Bätzing 2015). This paper presents examples of archaeological research carried out in the foothills of the Alps, inner-Alpine valley systems and high-Alpine landscapes.

\section{ARCHAEOLOGY OF THE FOOTHILLS OF THE ALPS: PILE DWELLINGS IN LAKES AND BOGS}

The Swiss Plateau is the biggest part of the area north of the Alps and one of three major landscapes in Switzerland. It is bordered in the northwest and north by the Jura massif and in the south by the Alps. Lakes Geneva and Constance mark the south-western and north-eastern boundaries of the Swiss Plateau, while the geological basin of the foothills themselves continue into parts of Germany, Austria and the French Savoy Alps.

The Swiss Plateau has always been and still is a densely settled landscape with large river valleys and lakes which act as centres of settlement (Fig. 2-3; Hasenfratz/Gross-Klee 1995). When studying the Neolithic period and Bronze Age in the circum-Alpine region in general and the Swiss Plateau in particular, one cannot avoid dealing with the well-known pile dwellings on lakes of all sizes, 
which have been inscribed on the list of UNESCO World Heritage sites since 2011. Thanks to 150 years of continuous archaeological and scientific research they are amongst the best-known archaeological sites in Europe, due in no small part to the extraordinary state of preservation of waterlogged and underwater sites where wood and other organic materials have survived the millennia. Finds and features, which would have decayed in mineral soil conditions, can still be examined. A great advantage of the excellent state of preservation is that the wooden piles of houses and palisades can be dated by dendrochronological means, which allows us to achieve high-resolution dates for these sites. Thanks to multi- and interdisciplinary research strategies adopted in the past three decades, a wealth of biological, dendrological, archaeological and dendrochronological data from lake-dwelling villages has provided us with reliable information on the chronological development, prehistoric subsistence economy and social organisation (Schibler et al. 1997; Jacomet et al. 2016; Doppler et al. 2010; Hafner/Suter 2000; Stöckli 2009). However, even with this data, some aspects will remain unclear or, as so often happens, give rise to new questions. Given that the villages were only inhabited for roughly one generation on average, sometimes even less and rarely more, the usual archaeological stable-locus models will fail to explain the pile-dwelling lifestyle. None of the models put forward so far have yet been fully accepted as explaining the often short-lived occupation and dynamic relocation of pile dwellings (Röder 2016; Ebersbach 2010; Hasenfratz/ Gross-Klee 1995). Unfortunately, it is not possible to create complete sequences of prehistoric lakeshore occupation based on dendrochronological data, since many sites suffered erosion or were destroyed by other means so that they can only be dated typochronologically. Due to reasons of research history and certain problems in relation to erosion and preservation, terrestrial sites are rather rare and have undergone less intensive research than the pile dwellings. This has led to a lack of information about dryland sites and it is difficult to ascertain as to whether there were any significant relationships and/or dependencies between lakeshore and dryland settlements. Moreover, many of the findspots in figures 2 and 3 are non-diagnostic individual or stray finds, which cannot be dated more precisely than to the Neolithic period or the Bronze Age. However, the distribution of finds clearly attests to a continuous occupation of certain landscapes on the Swiss Plateau during prehistoric times. We can state that during the entire prehistoric period the local communities on the Swiss Plateau were integrated into and participated in the different contemporary networks of communication, exchange and trade throughout Europe which introduced innovations, technologies, raw materials and goods that became part of people's lives and were adapted to their own specific needs (Hafner et al. 2016; Jennings 2014; Hafner/Suter 2003; Rychner 1998a). Because the Swiss Plateau covers a huge and heterogeneous territory with regard to its landscapes on one hand and the archaeological heritage on the other, this paper will focus on the plateau's western part with Lakes Morat, Neuchâtel and Bienne at its "centre".

\section{Neolithic period (5500 - 2200 BC)}

Early and Middle Neolithic (EN and MN), 5500 $4300 \mathrm{cal}$. BC, sites are rarely found in the western part of the Swiss Plateau, and they often still bear Mesolithic traits; this includes sites like rock shelters or caves. Only a small number of finds from the $6^{\text {th }}$ and early $5^{\text {th }}$ millennia attest to activities on the lakeshores and those cannot be linked directly to settlements. Nevertheless, we can state that the Early and Middle Neolithic settlement locations did not include the lakeshores at the foot of the Jura mountain range (Ebersbach et al. 2012; Mauvilly 2012).

The early part of the Upper Neolithic (UN), $4300-3900 \mathrm{BC}$, is known mainly from a few graves and cemeteries. However, the first signs of activity on or around the three lakes can also be identified (Ebersbach et al. 2012). The occupation of the lakeshores with pile dwellings began around 3900 BC and a general increase in human activity can be attested to in the first half of the $4^{\text {th }}$ millennium BC. The UN in western Switzerland was closely associated with the complex of the Cortaillod ceramic style and its communities stepped up the rate of occupation of the lakeshores and were the first to have a significant impact on their environment (Hafner/Suter 2003; Stöckli 1995). At the end of the UN, around $3500 \mathrm{BC}$, a hiatus in lakeshore settlement can be observed for the entire Swiss Plateau. It appears to have been linked with a rise in the lake levels during times of wetter climate and unfavourable conditions around the lakes (Magny 2004).

A short recurrence of settlement activity on the lakes during the Late Neolithic (LN), 3500 $2750 \mathrm{BC}$, is attested to by the remains of a few settlements dating from around $3400 \mathrm{BC}$ on Lakes Bienne, Morat and Neuchâtel. A more intense occupation of the lakeshores began once again around 3200 BC due to improved climate conditions (Magny 2004). The LN complexes of the Lattringen (3500 - 3000 BC) and Lüscherz (3000 - 2750 BC) pottery styles exhibit obvious links to the Horgen pottery complexes of the eastern foothills of the Alps, though regional preferences in pottery decorations and forms justify the separation of western and eastern Switzerland for the purposes of 
archaeological analysis (Hafner/Suter 2003; Stöckli 1995).

The final phase of the Neolithic period, 2750 2200 BC, was highly influenced by the Corded Ware Culture, though local pottery forms dominated and Corded Ware beakers and amphorae only became commonplace in pottery assemblages over time. Therefore, the western Swiss Corded Ware groups have been labelled Auvernier Cordé after the pile-dwelling site of Auvernier/La Saunerie on Lake Neuchâtel. The villages on all three lakes continued to thrive until $2400 \mathrm{BC}$ (Hafner/Suter 2003). After that there appears to have been a hiatus in lakeshore settlement due to climatic reasons until the Early Bronze Age (Magny 2004). In contrast to the Auvernier Cordé remains, sites associated with the Bell Beaker Culture, $2400-2200$ BC, are quite rarely found and show no direct links to the pile-dwelling lifestyle (von Burg 2002; Othenin-Girard 1997).

The exploitation of wild resources, including both plants and animals, had been an important factor in the prehistoric diet since the Mesolithic; though still very important in the UN, wild animals decreased in proportion in favour of domesticated animals. Subsistence strategies changed over time and can sometimes be associated with innovation in agriculture (manure, new plants), technology (animal traction, the wheel, metallurgy) or changing environmental conditions (more intense exploitation of wild resources). Interestingly, the settlements in western Switzerland had a larger proportion of sheep/goat in stock breeding than their neighbours in eastern Switzerland. This may have been due to the climate and environmental conditions which favoured sheep/goat breeding (Schibler 2008; Hafner/Suter 2003). From the LN onwards, the pile-dwelling settlements throughout the foothills of the Alps began to 'assimilate'. Houses were now arranged in serval parallel rows or in rows lining a pathway, forming a linear settlement (Strassendorf) (Hafner et al. 2016).

\section{Bronze Age (2200 - 800 BC)}

The chronological division and general development of the Bronze Age in Switzerland is based on the Central European scheme of Bronze Age phases according to Reinecke (Rychner 1998). During the Early Bronze Age (EBA), 2200 - 1600 BC, a shift in the settlement system towards the Alps can be detected, though the lakeshores continued to be settled throughout. The more intense occupation of regions that provided easy access to the inner-Alpine valley systems indicate an increased emphasis either on the trans-Alpine trade routes or on the exploitable metal resources of the Alps - or both. Evidence of increased human activity can be found at the outlet of Lake Thun (Canton Bern), at Lake Gruyère (Canton Fribourg) and in the region around Aigle, Ollon and Muraz (Cantons Vaud and Valais), three areas which provide the easiest access to the Alps. Interestingly, all these regions are near a lake or wetland which dominates the landscape (Hafner 2013). However, the overall density of EBA sites outside of the three regions mentioned decreased compared to the Final Neolithic.

The number of sites decreased even further during the Middle Bronze Age (MBA), 1600 $1300 \mathrm{BC}$. Thus, there is enough evidence to prove a continuous occupation of the Swiss Plateau (David-Elbiali 2000). A "collapse", "shrinking" or "changing" of the communities around 1600 BC has also been seen in other regions of Europe, e.g. at Kujawy, Poland or in the Carpathian Basin, Hungary (Kneisel 2012; Fischl et al. 2013), and may have been linked to a similar reduction of (traceable?) human activities.

The picture changes in the Late Bronze Age (LBA), $1300-800$ BC. Sites from this period are numerous and testify to the dense occupation of all landscapes on the Swiss Plateau. Most LBA sites have yielded finds from the $1^{\text {st }}$ millennium $B C$ onwards $(\mathrm{HaB})$. At that time the lakeshores once again became centres of human activity and pile dwellings seem to have played a significant role in the economic and social lives of the people living in the areas around the Alps (Jennings 2014; Rychner et al. 1998).

Although dryland settlements increased over the course of the Bronze Age, little is known about their dimensions and internal organisation. Pile dwellings remain our main source of evidence in relation to intra-settlement dynamics. As seen in the $L N$, the Bronze Age settlement layouts in the foothills of the Alps still consisted of several rows of houses (Benkert et al. 1998). In the Bronze Age wild animals played a minor role with regard to the diet but, as seen in the Neolithic period, animal bone assemblages from western Switzerland differ from those recovered from sites in eastern Switzerland by yielding a higher amount (and perhaps signifying a greater importance) of sheep/goats (Schibler/ Studer 1998). Palynological investigations point to an opening of the landscape due to agricultural intensification and the creation of pastureland (Rachoud-Schneider et al. 1998). One major change seen in the Bronze Age is the introduction and prevailing of cremation burials in the phase BzD associated with the pan-European phenomenon of the Urnfield Culture (Fischer 1998). Another feature of the LBA was the increased use of horses as means of transportation (Schibler/Studer 1998).

\section{Beyond the lake villages}

As part of the project "Beyond lake villages: Studying Neolithic environmental changes and human impact at small lakes in Switzerland, Ger- 
many and Austria", special emphasis is being put on reconstructing possible scenarios of interaction between humans and the environment in the Neolithic period and the Bronze Age. Therefore, modelling and simulation studies were incorporated into the project agenda, geared towards operating with different approaches on different spatial scales. Besides micro scale studies of land-use systems on the lakeshores themselves (see Baum et al. 2016; Baum 2016; Baum 2014), our work focuses on the larger geographical area of the Three-Lakes region in western Switzerland (see figs. 2-3), one of the most densely settled circum-Alpine regions in prehistoric times.

A top-down approach was chosen for the Three-Lakes region model, based on a sociocultural model of interaction between entire populations and realised by aggregate modelling of the characteristic and adaptive traits of the entities studied. The model operates in a geographical space and uses information on the availability of natural resources the social system is dependent on.

The major objective is to simulate Neolithic and Bronze Age population densities, subsistence strategies, land use and innovation. We employ a scaled-down version of the "Global Land Use and technological Evolution Simulator" (GLUES) which was previously used to estimate the impact of early farming societies on their environment (Lemmen 2010; Wirtz/Lemmen 2003). GLUES is defined by the adaptive dynamics of the four state variables of population density, technological efficiency, subsistence economy and economic diversity, by the resource utilities for each spatial unit, and by the spatial interaction between these units, e.g. migration and diffusion. Adaptive dynamics ensure that changes in important social characteristics optimise the overall benefit to a society at all times. Mathematically, this is achieved by stating that any change in a characteristic variable is proportional to its variability within the society and to the marginal value a change has for the growth rate of a population. A second objective is to provide insight into the vulnerability of past societies facing climate change. Several settlement studies on the Swiss Neolithic and Bronze Age have linked unfavourable climatic conditions to the temporary abandonment of the lakeshores (Schibler/Jacomet 2010; Arborgast et al. 2006; Magny 2004). The role played by the territories outside of the lakeshores in relation to the settlement system in western Switzerland, however, has not yet been studied in detail. Nevertheless, palynological and archaeological data suggest that the hinterlands of the big lakes were continuously occupied (Mauvilly 2012; Nielsen 2012, Reitmaier 2010). Thus, we are currently changing the existing models to explain the relationship between the lakeshores and hinterland in more detail. To this end we must refine the rough dichotomy between gathering and farming used by GLUES and replace it with a more detailed choice of economic strategies.

The existing models of interaction between humans and their environment, the landscape is often seen as a space of static, dynamic and changeable features where some can be defined as social and/or economic resources available to the local population (Nakoinz/Knitter 2016; Zimmermann 2014; Butzer 1982). Whilst we adopt the same perception of landscape in our study, we also view the recursive relationship between "natural" and "cultural" systems and landscapes as purely conceptual (Weichhart 2003; Ingold 1993).

\section{ARCHAEOLOGY OF THE INNER-ALPINE REGION: THE ALPINE RHINE VALLEY}

The Alpine Rhine Valley forms a direct gateway to the Alps, which begins in the north, in the region around Lake Constance to be exact. It is a broad valley landscape that leads to the central Alps, continues across inner-Alpine passes and southern-Alpine valleys and finally opens up into a region located between Lakes Maggiore and Como. In prehistoric times, this transit zone was not only used as an area of settlement and trade but also as a major thoroughfare into and across the Alps. Hence, the archaeological sites in the Alpine Rhine Valley were the subjects of numerous studies after 1930 , which resulted in the tentative conclusion that the valley had been continuously populated throughout every epoch between the Neolithic period and the Middle Ages. In addition, recent studies have shown that settlement and trade had not been limited to the valley floors but that they had also reached the high-Alpine regions towering above them (Reitmaier 2012b, 26; Zürcher 1982, 18-19). The topography of the Alpine region renders it ideal for archaeological scrutiny since the individual areas are strongly structured and divided into accessible settlement concentrations (valleys) which exhibit specific geomorphological and climatic parameters within which the individual economic potential varies greatly (Della Casa 2002, 7).

Unfortunately the Alps also have one major disadvantage: the archaeological sources are prone to greater falsifications due to topographical evolution such as changes in vegetation and erosion than is the case in other regions. Many sites remain undiscovered or are destroyed due to these conditions. As a direct consequence of this, the heritage preservation services have tended in the past to concentrate on archaeological studies and surveys of sites with recurring topographical features such as rock shelters, caves or geomorphological vantage points (hill crests or fissures) which provide archaeologists with a view of the surrounding area thus increasing the probability of 
finding other sites of interest (Della Casa 2002, 8; Barker 1995, 3).

The traditional view of archaeological sites and their analytical possibilities are in flux. In recent years construction projects such as motorways and car parks (Seifert 2012) have been valuable additions to the sources of information. Because their realisation requires extensive topographical restructuring and unprecedented surveys in relatively lightly populated areas, they provide us with a new understanding of the region, thus increasing our chances of making new discoveries. Insight into the settlement history and potential dispersion of prehistoric sites might also be gained from scientific and environmental surveys such as pollen analyses and soil profiles (Würfel et al. 2010; Röpke 2006; Röpke 2012). Though constant, the potential of any given landscape as a resource can be described and catalogued using environmental parameters (climate, vegetation and soil quality), specific mapping e.g. of rock, metal or ceramic groups and model applications. The utilisation of natural resources or lack thereof, however, is ultimately dependent on the cultural programming of the local populace (Della Casa 2002, 8).

\section{Neolithic period (5500-2200 BC)}

The Neolithic period in the Alps has been divided into different groups such as Hinkelstein, Cortaillod, Bocca quadrata, Rössen, Epi-Rössen, Lutzengüetle, Pfyn, Lagozza, Carasso-Tamins and Horgen. Only a few isolated Neolithic finds from the higher ranges of the Alps above the typical settlement areas in the valleys have been discovered amongst the bare rock, firn and ice of the Alpine peaks. Archaeologists have traditionally inferred from this rather low density of finds that the areas above the treeline had to have been uninhabitable. The latest scientific studies on the distribution of archaeological objects throughout the high valleys and mountain passes, however, contradict this assumption and suggest that the high Alps had already become part of the settlement catchment and land-use area of the Alpine populace by the $5^{\text {th }}$ millennium BC (Della Casa 2002, 18; Hafner 2015, 225; Reitmaier 2012b, 26).

After one hundred years of archaeological study, approximately sixteen archaeological sites have been identified in the Alpine Rhine Valley and a further three in the Val Mesolcina (GR) region south of the Alps (Fig. 4; Carazzetti 1986, 110-115; Della Casa 2000, 6; Donati 1986, 98; Maggetti 2009, 35; Seifert 2013, 123). They are located on hills or in troughs, fissures and beneath overhanging rocks. The oldest site is located in the Mesocco area (Della Casa 2000, 56; Rageth 1992, 22) and dates from the transition between the Mesolithic and Neolithic periods (c. 5000 BC). Further settlement structures have been recorded at Sevelen (SG) and Schellenberg, Borscht (FL) (Rigert et al. 2005, 62; Maczynska 1999, 30; Seifert 2004, 19) and a settlement dating from $4800 / 4500 \mathrm{BC}$ was recently excavated at Zizers, Friedau (GR) (Seifert 2012, 79). The majority of ceramic objects in the assemblage recovered from this settlement can be attributed to the Hinkelstein Culture of south-western Germany (mainly Rhine-Hesse) but other artefacts suggest a link to the ceramic traditions south of the Alps (Seifert 2012, 93). The most important archaeological site in the central Alps is located at Gamprin, Lutzengüetle (FL) and has yielded exceptional finds dating from the $4^{\text {th }}$ millennium BC (Beck 1942; Beck 1943; Beck 1944; Hartmann-Frick 1959; Vogt 1945; Hafner/Suter 2003; Hafner/Suter 2005; Heeb 2012, 316).

Only a limited number of radiocarbon dates from the Neolithic period existed up to now, the best of which came from the assemblages recovered from Sevelen, Pfäfersbüel (Rigert et al. 2005, 61) Zizers, Friedau (Seifert 2012, 93) and Tamins, Crestis (Primas 1979). As part of this project new radiocarbon dates from Gamprin, Lutzengüetle have been obtained by the Department of Chemistry and Biochemistry at the University of Bern.

\section{Bronze Age (2200-800 BC)}

The Bronze Age was a period of intensive prehistoric expansion in the Alps (Della Casa 2002, 61; Primas 1998, 355), both in the valleys and in the regions above $2500 \mathrm{~m}$ a.s.l. This expansion of agricultural land ran parallel to a prevalent intensification of economic activities, the integration of the settlements into extensive communication networks (Della Casa et al. 2009, 194; Reitmaier/Della Casa $2010,30)$ and a considerable increase in the range of these networks (Primas 1998, 355; Reitmaier/ Della Casa 2010, 30). The number of archaeological sites dating from the Bronze Age is considerably higher than that from the Neolithic period. Demographic aspects were presumably only some of many reasons that led to the rapid expansion and agglomeration of the populated areas in the Alps during the $2^{\text {nd }}$ millennium $B C$. It is possible that an increase in the demand for land that could be used for farming and animal husbandry, new commercial activities and the economically more favourable locations of valleys and mountain passes were the motivating factors behind this proliferation. The exchange and trade of various goods implies a system of commercial relationships, which was unexpectedly wide-ranging by Bronze Age standards (Reitmaier/Della Casa 2010, 34). This is further illustrated by spectral analyses carried out on amber beads recovered from the settlements at Wartau, Ochsenberg Savognin, Padnal and Surin in Crestaulta (Primas 2004, 55; Rageth 1976, 173; Bur- 
kart 1946, 18) which suggest that the amber had come from the region of the Baltic Sea. This is proof of long-distance trade relationships (Primas 2004, 55; Primas 2013).

The majority of settlement locations in the central Alps that date from the Bronze Age are categorised as high-altitude settlements (Fig. 5). They occupy dominant topographical features such as hilltops and plateaus and are located on lynchets or on rock ledges (Von Uslar 1991, 51). Some of the pottery recovered from various excavations shows definite links to the southern Alps (Marzatico 2002, 29; Primas 1998, 361) and the Trentino region in particular (Stöckli 2016, 190; 194 Abb. 133, 12).

The settlement sites at Savognin, Padnal (Rageth 1986, 64-75) and Cazis, Cresta (Murbach-Wende 2016; Wyss 2002, 17-26) are the best-stratified and most firmly dated assemblages in the central Alps, making them the most prominent Bronze Age settlements in the study area (Rageth 1986, 95; Fasnacht 1999, 274; Murbach-Wende 2000, 75). The age determination and archaeological results imply a continuous settlement evolution from the Early to the Late Bronze Age which is similar to the occupation period observed at other settlements, e.g. Koblach, Kadel, Falera, Muota and Salouf, Motta Vallac (Fetz 1982, 151; Vonbank 1966, 56-57; Thomas 1974, Taf. 1-32; Wyss 1982, 77). In addition, Burkhart's study on the settlement remains from Lumbrein/Surin, Crestaulta (Burkart 1946, 22-28) in the Lumnezia Valley showed that the archaeological findings and architectural characteristics of the settlements in the Alpine regions differed from the sites on the Swiss Plateau.

Burial finds from the central Alps are limited in number but nonetheless have been attested to for every epoch between the Early, Middle and Late Bronze Ages (Fig. 6). However, there are significant chronological differences between these burials. Typically, the deceased were buried in individual graves or small cemeteries (Seifert 2008, 25) with no indications as to which settlement they might have belonged to. The cremation cemetery at "Cresta Petschna" in the Lugnez region (GR) (Burkart 1948; Burkart 1949; Bill 1979) with its associated settlement at "Crestaulta" (Burkart 1946) is the exception to this rule. Even if we assume that only a small part of the deceased were, in fact, interred, the amount of documented graves is nonetheless strikingly low, given that the few known burials spread over a period of 1300 years (Seifert 2008, 25). Of course, burials are often overlooked and destroyed during construction, especially if they are scattered over a relatively vast area and were not clearly marked (Seifert 2008, 25). If, in addition, the graves only contain urns and are therefore very small, their chances of discovery decrease signifi- cantly, making their detection a game of luck at best.

In the Early Bronze Age inhumation was the usual type of burial (Burkart 1942, 353; KellerTarnuzzer 1933; Stehrenberger 2012, 147), with some graves containing double inhumations (Burkart 1942; Mayr/Stehrenberger 2012; Stehrenberger 2012). Numerous discoveries in the Alpine Rhine Valley suggest that burials in caves were also commonplace (Keller-Tarnuzzer 1933; Nagy 1996, 61; Rigert 2005, 241). The cremation burial site of Cresta Petschna near Surin is the only Middle Bronze Age cemetery known to date (Burkart 1948, 8; Burkart 1949, 36; Spindler 1973, 62-71) and only a few burials containing Late Bronze Age grave goods have so far been found (Ballmer 2015; Janke 1991; Primas 1972; Seifert 1997).

Numerous isolated finds have been recovered around the mountain passes at altitudes above $2000 \mathrm{~m}$ a.s.l. and most have been categorised as ritual offerings (Wyss 1996, 417). Bronze Age hoards are mainly characterised by the repetition and standardisation of certain, predominantly metallic object groups and are thought to be of ritual origin. Occasionally they are put into relation with the location of discovery; these include rivers, lakes and bogs (Ballmer 2010; Ballmer 2015; Ballmer 2016; Reitmaier/Della Casa 2010, 35). Given the mobility of the inner-Alpine population, it strikes one that the two solid-hilted swords deposited in the $15^{\text {th }}$ century $B C$ near the tapping of a spring at St. Moritz seem to have originated in southern Germany (Reitmaier 2012a, 113; Kristiansen/Suchowska-Ducke 2015; Seifert 2000, 64).

The study area underwent drastic changes in the Late Bronze Age and northern influences grew increasingly stronger in the Alpine Rhine Valley, stretching as far as the northern and central Grisons. Laugen-Melaun pottery from the South Tyrol region was a new type of ceramic vessel introduced in the Lower Engadine and the Alpine Rhine Valley (Caduff 2007, 35-40; Hild 1937, 39; Hild 1939, 205; Rageth 1998, 72; Stauffer 1976, 149; Stauffer-Isenring 1983, 100-107; SteinhauserZimmermann 1989, 29). According to thin-section analyses on Laugen-Melaun pottery from Ardez, Scuol at Ramosch, a substantial portion of this new type of pottery was imported directly from the region around Bolzano (South Tyrol) (Maggetti et al. 1982; Stauffer-Isenring 1983, 98-101). The situtation in the Alpine Rhine Valley was markedly different since only a small amount of Laugen-Melaun pottery was imported and the majority was of local origin and manufacture (Maggetti et al. 1982, 176). In contrast to the northern regions, the southern parts of the study area were more strongly influenced by the Ticino and Lombardy regions (Rageth $2000,16)$. 
In order to better understand mobility and cultural transfer in the Alps, funerary rites, settlement structures and different types of economic systems were analysed and catalogued over time. The motivations and patterns of prehistoric settlement activities in the Alpine region were determined by a variety of factors, which can be deduced by means of a detailed evaluation of the regional topographical conditions. The exact localisation of archaeological sites, the evaluation of their past functions and, finally, the scientific analysis of the finds have allowed us to draw new conclusions regarding the chronological and spatial evolution of each settlement. Such deductions, however, are subject to certain preconditions: the sites in question must contain recognisable residential structures (dwellings), traces or structures of activity or places that were either used for resource exploitation or production (mines or smelting places) and show permanent, or at least seasonal, settlement activities. Hoards and isolated finds point to the targeted and at least temporary usage of a region (Della Casa 1998, 367).

The fundamental question is why the settlement rate in the Alpine region increased so drastically over the course of the Neolithic period and the Bronze Age. E.S. Lee's migration theory (Lee $1966,47-57)$ provides a possible answer. He states that people are 'pushed away' from their region of origin, are 'pulled towards' a different region and have to negotiate any obstacles they encounter en route. Between 3500 and 2500 BC the Alpine region was subjected to numerous economic crises and the resulting socio-economic consequences raised the probability of the afflicted regions experiencing a push effect towards more peripheral and less densely populated regions (Della Casa 2002, 63). Ecological and economic parameters suggest that practically every major settlement site in the Alpine region underwent a gradual relocation to the inner-Alpine region (Della Casa 2002, 18). Isolated finds and hoards seem to indicate that settlement and burial locations experienced a shift towards major traffic axes and that bigger sites with continuous settlement phases were established at strategically advantageous locations (Della Casa 1998, 368). These observations suggest that a wide variety of local resources, new territories and strategically controllable regions were having a pull effect on the populace at the time.

\section{ARCHAEOLOGY OF HIGH-ALPINE LANDSCAPES: THE BERNESE ALPS}

In the European Alps archaeological finds from landscapes above the treeline and at altitudes of more than $2000 \mathrm{~m}$ a.s.l. are quite rare. Before 1991 most researchers were convinced that highAlpine landscapes had not been of any interest to Neolithic farming communities and economic motivations were only attributed to Mesolithic hunters or Bronze Age herders. The discovery of a Neolithic ice mummy at the Tisenjoch pass (Tyrolean Alps of Italy and Austria) at the extraordinary high altitude of $3208 \mathrm{~m}$ a.s.l. in 1991 led archaeologists to rethink how Neolithic communities may have used these at first glance inhospitable zones. Vertical mobility within high mountain areas was obviously much more developed than previously believed. Twelve years later, in 2003, a melting ice field on the Schnidejoch Pass ( $2756 \mathrm{~m}$ a.s.l.) in the western Bernese Alps of Switzerland yielded several hundred objects from the Neolithic period, the Bronze and Iron Ages and from Roman and early medieval times (Hafner 2015; Fig. 7). The oldest finds date from the beginning of the $5^{\text {th }}$ millennium $B C$, whilst the most recent artefacts date from around AD 1000. The total time span covered by archaeological finds is almost 6000 years (Fig. 8). Most of the objects date from the Neolithic period and the Bronze Age and are of organic origin. A series of over 70 radiocarbon dates confirms that the Schnidejoch Pass, which linked the Bernese Uplands with the Rhône Valley, was frequented from no later than $4800-4500$ BC onwards. The pass was easily accessible when the glaciers descending from the nearby Wildhorn mountain range (summit at $3248 \mathrm{~m}$ a.s.l.) entered a retreating phase (Grosjean et. al 2007). On the other hand, the area was impassable during periods of glacial advances. A recent palaeoecological study of sediment cores from nearby Lake Iffigsee ( $2065 \mathrm{~m}$ a.s.l.) provides clear evidence of early human impact in this Alpine area. Linking archaeological finds from the Schnidejoch Pass and the Rhône Valley with the palaeoecological data provides results that can be interpreted as indications of early Alpine pastoralism and transhumance from the $5^{\text {th }}$ millennium BC onwards (Fig. 9; Hafner/Schwörer 2017). Further high-Alpine sites confirming mobility in the western Bernese Alps are the Lötschen Pass at $2690 \mathrm{~m}$ a.s.l. and the Tierberg rock shelter at $2660 \mathrm{~m}$ a.s.l. (Hafner 2015). The oldest finds from the Lötschen Pass, including several bows that also melted out of the ice, date from the Early Bronze Age, i.e. the centuries between 2000 and 1600 BC. As on the Schnidejoch Pass the sequence of dated finds ends with medieval material. A flint arrowhead from excavations carried out in the 1930s at the Tierberg rock shelter is the only evidence pointing to a prehistoric, probably Neolithic use of the area to set up a high-Alpine campsite. At the time the excavators noticed thick layers of charcoal from hearths but datable samples, which could deliver a precise date, are not currently available.

High-Alpine passes and rock shelters confirm that the zones above the treeline were part of the economic system of prehistoric communities and 
the earliest data from the Schnidejoch Pass suggest a date around 4800/4500 BC. Passes obviously linked with mobility and rock shelters may have offered shelter to small groups of people for short periods of no more than a few days. Still missing from the archaeological record are sites at medium altitudes that are suitable for seasonal stays during the summer months in relation to high-Alpine pastoralism. So far, the presence of humans and their impact has only been attested to by palaeoecological studies. Archaeological evidence of campsites directly related to Alpine pastoralism from the Neolithic period has not yet been found.

\section{SYNTHESIS}

This paper presents examples of landscape archaeological research within an Alpine context. The landscapes around and within the European Alps are highly diversified. The most significant differences lie in the altitudes, which range between 400 and over $3000 \mathrm{~m}$ a.s.l. Main topographic features are hilly pre-Alpine areas, broad inner-Alpine valleys reaching far into the Alps and high-Alpine zones above the treeline. Our examples span from wetland-related pile dwellings on lakes and bogs from the pre-alpine areas, graves and settlements on inner-Alpine hilltops and river terraces to high-Alpine passes and campsites. Archaeological evidence shows that settlement activities began to occur in all regions presented from the early $5^{\text {th }}$ millennium BC onwards. Palaeoecological evidence from the pre-Alpine areas could even push this timeline back to the mid-6th millennium BC (Tinner et al. 2007). We can assume a high degree of mobility between all these regions. Whilst lake and bog settlements have been known for a long time and have been studied in detail, research- ers only began to focus on high-Alpine areas two decades ago. The Alps and their surrounding preAlpine landscapes are a fascinating area of archaeological research especially in terms of the period of the first farmers. Whilst we are constantly gaining a better understanding of how early agrarian societies managed to penetrate from different pre-Alpine lowland areas to the zones above the treeline, we are still far from being able to paint a clear picture. The long-term evolution of human settlement activities turned the pre-Alpine regions and parts of the large inner-Alpine valleys from pristine landscapes into urban spaces with small inner-Alpine valleys and areas above the treeline developing highly sustainable land-use activities that have left their mark on the cultural landscapes of the Alps.

Acknowledgements: This article was produced with the support of the Swiss National Science Foundation (SNSF) for the projects "Beyond lake settlements: Studying Neolithic environmental changes and human impact at small lakes in Switzerland, Germany and Austria (CR20l1L_152862)" and "Chronology, mobility and cultural transfer. A landscape archaeological study of the central Alps (POBEP1_165306)". Conference participation and the public lecture in Kiev was possible due to an Institutional Partnership (SCOPES) grant for the project "Networking in Eastern European Neolithic and Wetland Archaeology for the improvement of field techniques and dating methods (IZ74Z0_160469)". The authors would like to thank Sandy Hämmerle, Galway, for proofreading the manuscript. We would also like to thank the Departments of Heritage Management of Cantons Bern, Solothurn, Luzern and Vaud for making their regional archaeological databases available to us. 


\section{REFERENCES}

\section{Arborgast et al. 2006}

R.-M. Arborgast/S. Jacomet/M. Magny/J. Schibler, The Significance of Climate Fluctuations for Lake Level Changes and Shifts in Subsistence Economy During the Late Neolithic (4300-2400 B.C.) in Central Europe. Vegetation History and Archaeobotany $15 / 4,2006,403-418$.

\section{Ballmer 2010}

A. Ballmer, Zur Topologie des bronzezeitlichen Deponierens Von der Handlungstheorie zur Raumanalyse, Prähistorische Zeitschrift 85, 120-131.

\section{Ballmer 2015}

A. Ballmer, Topografie bronzezeitlicher Deponierungen. Fallstudie Alpenrheintal, Universitätsforschungen zur Prähistorischen Archäologie 278 (Bonn 2015).

\section{Ballmer 2016}

A. Ballmer, YOU ARE HERE. Orientierung und Erinnerung in den Graubündner Alpen $(\mathrm{CH})$ im 2. Jahrtausend v. Chr., in: S. Hansen/D. Neumann/T. Vachta (Hrsg.), Raum, Gabe und Erinnerung. Weihgaben und Heiligtümer in prähistorischen und antiken Gesellschaften, Berlin Studies of the Ancient World 38 (Berlin 2016), 55-74.

\section{Barker 1995}

G. Barker, Landscape Archaeology in Italy - Goals for the 1990s, in: N. Christie (Hrsg.), Settlement and Economy in Italy 1500 BC - AD 1500, Oxbow Monograph 41 (Oxford 1995) 1-11.

\section{Bätzing 2015}

W. Bätzing, Die Alpen - Geschichte und Zukunft einer europäischen Kulturlandschaft. C.H.Beck, München 2015, 4. Auflage. 484 p.

\section{Baum 2014}

T. G. Baum, Models of Wetland Settlement an Associated Land Use in South-West Germany During the Fourth Millennium B.C. Vegetation History and Archaeobotany 23/Suppl. 1, 2014, 67-80.

\section{Baum 2016}

T. Baum, Simulating Land Use of Prehistoric Wetland Settlements: Did Excessive Resource Use $\mathrm{Ne}$ cessitate a Highly Dynamic Settlement System? In: J.A. Barceló/F. DelCastillo (Hrsg.), Simulating Prehistoric and Ancient Worlds. Springer Computational Social Sciences, 233-254. doi: 10.1007/978-3-319-31481-5.

\section{Baum et al. 2016}

T. Baum/C. Nendel/S. Jacomet/M. Colobran/R. Ebersbach, "Slash and Burn" or "Weed and Manure"? A Modelling Approach to Explore Hypotheses of Late Neolithic Crop Cultivation in Pre-Alpine wetland Sites. Vegetation History and Archaeobotany 25/6, 2016, 611-627.

\section{Beck 1942}

D. Beck (1942), Ausgrabung auf dem Eschner-Lutzengüetle 1942, Jahrbuch des Historischen Vereins für das Fürstentum Liechtenstein 42, 73-84.

\section{Beck 1943}

D. Beck (1943), Ausgrabung auf dem Eschner Lutzengüetle 1943, Jahrbuch des Historischen Vereins für das Fürstentum Liechtenstein 43, 71-83.

\section{Beck 1944}

D. Beck (1944), Ausgrabungen auf dem Eschner Lutzengüetle 1944, Jahrbuch des Historischen Vereins für das Fürstentum Liechtenstein 44, 93-109.

\section{Bill 1979}

J. Bill (1979), Grab 4 der Nekropole Cresta Petschna im Lugnez, Archäologie der Schweiz 2, 75-77.

\section{Borrello et al. 2011}

M. A. Borrello/E. Mottes/H.Schlichtherle 2011. Traverser le Alpes au Néolithique. In: Les hommes préhistoriques et les Alpes, M. A. Borrello (editor). Document du Département de géographie et environnement de I'Université de Genève (2011), British Archaeological Reports, International Series 2476, 2013), p. 27-40.

\section{Benkert et al. 1998}

A. Benkert/R. Carazzetti/H. Gollnisch/J. Rageth/M. Seifert, 3. Siedlungswesen. In: S./Hochuli/U. Niffeler/V. Rychner (Hrsg.), SPM III. Bronzezeit (Basel 1998), 193-231.

\section{von Burg 2002}

A. von Burg, Die Glockenbecherkultur auf dem Plateau von Bevaix. Archäologie Schweiz 25, 2002, 48-57.

\section{Burkart 1942}

W. Burkart (1942), Das Kuppelgrab von Donath, Bündnerisches Monatsblatt 12, 353-364.

\section{Burkart 1946}

W. Burkart, Crestaulta. Eine bronzezeitliche Hügelsiedlung bei Surin im Lugnez, Monographien zur Ur- und Frühgeschichte der Schweiz (Basel 1946).

\section{Burkart 1948}

W. Burkart (1948), Die Grabstätten der CrestaultaSiedler, Ur-Schweiz. Mitteilungen zur Ur- und Frühgeschichte der Schweiz 12,1, 5-9.

\section{Burkart 1949}

W. Burkart (1949), Die bronzezeitliche Teilnekropole am Cresta petschna, Ur-Schweiz. Mitteilungen zur Ur- und Frühgeschichte der Schweiz 13,3, 35-39.

\section{Butzer 1982}

K.W. Butzer, Archaeology as Human Ecology: Method and Theory for a Contextual Approach (New York 1982).

\section{Caduff 2007}

B. Caduff, Ardez - Suotchastè. Eine urgeschichtliche Fundstelle im Unterengadin (GR), Separatdruck aus dem Jahrbuch der historischen Gesellschaft in Graubünden (Chur 2007).

\section{Carazzetti 1986}

R. Carazzetti (1986), La ceramica neolitica di Bellinzona, Castel Grande: prime osservazioni, Archäologie der Schweiz 9/3, 110-115.

David-Elbiali 2002

M. David-Elbiali, La Suisse occidentale a lle millénaire av. J.-C. Chronologie, culture, intégration euro- 
péenne. Cahiers d'archéologie romande 80 (Lausanne 2000).

\section{Della Casa 1998}

P. Della Casa, Relief, Boden Klima. Zusammenhänge zwischen Landschaften und Siedlungsmuster am Beispiel der Täler nördlich und südlich des San Bernardino, in: B. Hänsel (Hrsg.), Mensch und Umwelt in der Bronzezeit Europas. Die Bronzezeit: das erste goldene Zeitalter Europas (Kiel 1998).

\section{Della Casa 2000}

P. Della Casa, Mesolcina Praehistorica. Mensch und Naturraum in einem Bündner Südalpental vom Mesolithikum bis in römische Zeit, Universitätsforschungen zur Prähistorischen Archäologie 67 (Bonn 2000).

Della Casa 2002

P. Della Casa, Landschaften, Siedlungen, Ressourcen. Langzeitszenarien menschlicher Aktivität in ausgewählten alpinen Gebieten der Schweiz, Italiens und Frankreichs, Préhistoires 6 (Montagnac 2002).

Della Casa et al. 2009

P. Della Casa/E. Jochum Zimmermann/C. Jacquat (2009), Eine alpine Siedlung der Bronze- und Eisenzeit in Airolo- Madrano (KT. Tessin, Schweiz). Archäologische und paläoökologische Grundlagen, Archäologisches Korrespondenzblatt 39/2, 193-211.

\section{Donati 1986}

P. Donati (1986), Bellinzona a Castel Grande: 6000 anni di storia, Archäologie der Schweiz 9/3, 94-109.

Doppler et al. 2010

T. Doppler/S. Pichler/S. Jacomet/J. Schibler/B. Röder, Archäobiologie als sozialgeschichtliche Informationsquelle: ein bisher vernachlässigtes Forschungspotential. In: E. Classen/T. Doppler/B. Ramminger (Ed.), Familie - Verwandtschaft - Sozialstrukturen: Sozialarchäologische Forschungen zu neolithischen Befunden. Fokus Jungsteinzeit. Berichte der AG Neolithikum 1 (Kerpen-Loogh 2010), 119-139.

\section{Ebersbach 2010}

R. Ebersbach, Seeufersiedlungen und Architektursoziologie - eine Anwendungsversuch. In: P. Trebsche/N, Müller-Scheeßel/S. Reinhold (Ed.), Der gebaute Raum. Bausteine einer Architektursoziologie vormoderner Gesellschaften. Tübinger Archäologie Taschenbücher 7 (Münster 2010), 193-212.

Ebersbach et al. 2012

R. Ebersbach/M. Kühn/B. Stopp, Die Nutzung neuer Lebensräume in der Schweiz und angrenzenden Gebieten im 5. Jtsd. v. Chr.: siedlungs- und wirtschaftsarchäologische Aspekte. Jahrbuch Archäologie Schweiz 95, 2012, 7-34.

\section{Fasnacht 1999}

W. Fasnacht, Prähistorischer Kupferbergbau im Oberhalbstein und dessen Spuren in der bronzezeitlichen Siedlung Savognin - Padnal (GR), in: P. Della Casa (Hrsg.), Prehistoric alpine environment, society, and economy. Papers of the international colloquium PAESE '97 in Zürich, Universitätsfor- schungen zur prähistorischen Archäologie 55 (Zürich 1999) 267-276.

\section{Fetz 1982}

H. Fetz, Die Urgeschichtliche Siedlung Koblach-Kadel im Vorarlberger Alpenrheintal. Unpublizierte Dissertation. (1982).

\section{Fischer 1998}

C. Fischer, 5. Symbolische Handlungen und Bestattungsbräuche in der Bronzezeit. In: S./Hochuli/U. Niffeler/V. Rychner (Hrsg.), SPM III. Bronzezeit (Basel 1998), 309-326.

\section{Fischl et al. 2013}

K. Fischl/V. Kiss/G. Kulcsár/V. Szeverényi, Transformations in the Carpathian Basin around 1600 B.C. In: H. Meller/ F. Bertemes/H.-R. Bork/R. Risch (Hrsg.), 1600. Kultureller Umbruch im Schatten des TheraAusbruchs? [Symposium Halle 2011]. Tagungen des Landesmuseums für Vorgeschichte Halle 9 (Halle 2013) 355-372.

\section{Grosjean et al. 2007}

M. Grosjean, P.J. Suter, M. Trachsel and H. Wanner, Ice-born prehistoric finds in the Swiss Alps reflect Holocene glacier fluctuations. In: Journal of Quaternary Science, Vol. 22, 3: 203-207.

\section{Hafner 2013}

A. Hafner, Frühbronzezeitliche Gräber der unteren Thunerseeregion. In: Erziehungsdirektion und $\mathrm{Ar}$ chäologischer Dienst des Kanton Bern (Hrsg.), Die Pfahlbauer. Am Wasser und über die Alpen (Bern 2013), 30-35.

\section{Hafner 2015}

A. Hafner, Schnidejoch und Lötschenpass. Archäologische Forschungen in den Berner Alpen / Schnidejoch et Lötschenpass. Investigations archéologiques dans les Alpes bernoises. 2 Volumes (Bern 2015), $524 \mathrm{p}$.

Hafner/Schwörer 2017

A.Hafner, C. Schwörer, Vertical mobility around the high-alpine Schnidejoch Pass. Indications of Neolithic and Bronze Age pastoralism in the Swiss Alps from paleoecological and archaeological sources, Quaternary International, 22.03.2017 (in press), doi: $10.1016 /$ j.quaint.2016.12.049

\section{Hafner/Suter 2000}

A. Hafner/P.J. Suter, -3400. Die Entwicklung der Bauerngesellschaften im 4. Jahrtausend v. Chr. Am Bielersee aufgrund der Rettungsgrabungen von Nidau und Sutz-Lattrigen. Ufersiedlungen am Bielersee 6 (Bern 2000).

Hafner/Suter 2003

A. Hafner/P.J. Suter (2003), Das Neolithikum in der Schweiz, Journal of Neolithic Archaeology 5, 1-75.

\section{Hafner/Suter 2005}

A. Hafner/P.J. Suter (2005), Neolithikum: Raum/ZeitOrdnung und neue Denkmodelle, Archäologie im Kanton Bern 6B, 431-498.

\section{Hafner et al. 2016}

A. Hafner/P. Pétrequin/H. Schlichtherle, Ufer- und Moorsiedlungen. Chronologie, kulturelle Vielfalt und Siedlungsformen. In: Archäologisches Landesmuseum Baden-Württemberg/Landesamt für Denkmalpflege im Regierungspräsidium Stutt- 
gart (Hrsg.), 4000 Jahre Pfahlbauten (Ostfildern 2016), 59-64.

\section{Hartmann-Frick 1959}

H. Hartmann-Frick (1959), Die Tierwelt des prähistorischen Siedlungsplatzes auf dem Eschner Lutzengüetle Fürstentum Liechtenstein (Neolithikum bis La Tène), Jahrbuch des Historischen Vereins für das Fürstentum Liechtenstein 59, 5-223.

\section{Hasenfratz/Gross-Klee 1995}

A. Hasenfratz/ E. Gross-Klee, 5. Siedlungswesen und Hausbau. In: W.E. Stöckli/U. Niffeler/E. Gross-Klee (Hrsg.), SPM II. Neolithikum (Basel 1995), 195-230.

\section{Heeb 2012}

B.S. Heeb, Das Bodenseerheintal als Siedlungsraum und Verkehrsweg in prähistorischen Epochen. Eine siedlungsarchäologische Untersuchung, Frankfurter Archäologische Schriften 20 (Bonn 2012).

\section{Hild 1937}

A. Hild, Funde auf dem Montikel zu Bludenz, in: O. H. Menghin (Hrsg.), Die vorgeschichtlichen Funde Vorarlbergs, Österreichische Kunsttopographie (Baden bei Wien 1937) 38-41.

\section{Hild 1939}

A. Hild, Die Siedlungs- und Grabfunde von Bludenz, Mitteilungen der prähistorischen Kommissionen der Akademie der Wissenschaften 3 (Wien 1939).

\section{Ingold 1993}

T. Ingold, The Temporality of the Landscape. World Archaeology 25/2, 1993, 152-174.

\section{Janke 1991}

R. Janke, Le necropoli dell'età del bronzo dal territorio dell'attuale canton ticino (Svizzera), Unpublizierte Lizentiatsarbeit. Universität Bern (1991).

\section{Jennings 2014}

B. Jennings, Breaking with Tradition. Cultural Influences for the Decline of the Circum-Alpine Region Lake-Dwellings (Leiden 2014).

\section{Jacomet et al. 2016}

S. Jacomet/R. Ebersbach/é. Akeret/F. Antolín/T. Baum/A. Bogaard/C. Brombacher/N.K. Bleicher/A. Heitz-Weniger/H. Hüster-Plgmann/E. Gross/M. Kühn/P. Rentzel/B.L. Steiner/L. Wick/J. Schibler, On-Site Data Cast Doubts on the Hypothesis of Shifting Cultivation in the Late Neolithic (c. 43002400 cal. BC): Landscape Management as an Alternative Paradigm. The Holocene 26/11, 2016, 1858-1874.

\section{Keller-Tarnuzzer 1933}

K. Keller-Tarnuzzer (1933), Eine Grabhöhle auf der Hahnenspielalpe Vaduz, Jahrbuch des Historischen Vereins für das Fürstentum Liechtenstein 33, 49-54.

\section{Kneisel 2012}

J. Kneisel, The Problem of the Middle Bronze Age Inception in Northeast Europe. Or: Did the Únĕtice Society Collapse? In: J. Kneise/W. Kirleis/M. Dal Corso/N. Taylor/V. Tiedtke, Collapse or Continuity? Environment and Development of Bronze Age Human Landscapes [Symposium Kiel 2011] (Bonn 2012), 209-233.

\section{Kristiansen/Suchowska-Ducke 2015}

K. Kristiansen/P. Suchowska-Ducke (2015), Connected Histories: the Dynamics of Bronze Age Interaction and Trade 1500-1100 BC, Proceedings of the Prehistoric Society 81, 361-392.

Lee 1966

Lee, E. S. (1966), A Theory of Migration, Demography 5/1, 47-57.

\section{Lemmen 2010}

C. Lemmen, World Distribution of Land Cover Changes During Pre- and Protohistoric Times and Estimation of Inducted Carbon Releases. Géomorphologie: relief, processus, environment 4, 2009 (2010), 303-312.

\section{Maczynska 1999}

M. Maczynska, Schellenberg-Borscht. Ein prähistorischer Siedlungsplatz im Fürstentum Liechtenstein, Befunde, Keramik, Metallfunde, I (Schaan 1999).

\section{Maggetti 2009}

M. Maggetti, Neolithic pottery from Switzerland: raw materials and manufacturing processes, in: A. J. Shortland / I. C. Freestone / T. Rehren (Hrsg.), From Mine to Microscope. Advances in the Study of Ancient Technology (Oxford 2009) 29-42.

\section{Maggetti et al. 1982}

M. Maggetti/L. Stauffer/ M.-M. Waeber (1982), Zur Produktion der inneralpinen Laugen-Melaun Keramik in Liechtenstein. Ergebnisse und Interpretation von mineralogischen Keramikanalysen, Jahrbuch des Historischen Vereins für das Fürstentum Liechtenstein 82, 153-178.

\section{Magny 2004}

M. Magny, Holocene Climate Variability as Reflected by Mid-European Lake-Level Fluctuations and Its Probable Impact on Prehistoric Human Settlements. Quaternary International 113, 2004, 65-79.

\section{Mayer/Stehrenberger 2012}

U. Mayr/T. Stehrenberger(2012), Triesen FL, Fürst Johann-Strasse (0985), Jahrbuch Archäologie Schweiz 95, 174-175.

\section{Marzatico 2002}

F. Marzatico, "Mobilität" entlang des Etschtals vor der Romanisierung, in: G. Schnekenburger (Hrsg.), Kulturelle Beziehungen zwischen den Regionen nördlich und südlich der Zentralalpen während des Neolithikums und der Kupferzeit, ALManach 7/8 (Stuttgart 2002) 23-37.

\section{Mathieu 2015}

J. Mathieu, Die Alpen. Raum - Kultur - Geschichte. Stuttgart. $254 \mathrm{p}$.

\section{Mauvilly 2012}

M. Mauvilly, Entre lac e montagne: l'occupation du Plateau suisse du Mésolithique à l'âge du Bronze en regard des établissements littoraux, l'exemple du canton de Fribourg (Suisse). In: M. Honegger/C. Mordant (ed.), L'Homme au bord de l'eau. Archéologie des zones littorales du Néolithique à la Protohistoire. Cahiers d'Archéologie Romande 132. Documents Préhistoriques 30 (Lausanne/Paris 2012), 261-283. 


\section{Murbach-Wende 2000}

I. Murbach-Wende, Die frühbronze- bis eisenzeitliche Keramik der Siedlung Cazis-Cresta (GR). Eine Entwicklungsgeschichte über 1500 Jahre, Inauguraldissertation (Bern 2000).

\section{Murbach-Wende 2016}

I. Murbach-Wende, Cazis, Cresta: Die Keramik, Archäologie in Graubünden 5, 1 (Chur 2016).

Nagy 1996

P. Nagy (1996), Das Neolithikum im Kanton St. Gallen, Helvetia Archaeologica 27 (106/108), 52-63.

\section{Nakoinz/Knitter 2016}

O. Nakoinz/ D. Knitter, Modelling Human Behaviour in Landscapes. Basic Concepts and Modelling Elements (Wien/New York 2016).

\section{Nielsen 2012}

E. Nielsen, Neolithische Landsiedlungen zwischen Napf und Rigi. In: A. Boschetti-Maradi/A. De Capitani/S. Hochuli/U. Niffeler (Hrsg.), Form, Zeit und Raum. Grundlagen für eine Geschichte aus dem Boden [Festschrift W. E. Stöckli]. Antiqua 50 (Basel 2012), 47-61.

\section{Othenin-Girard 1997}

B. Othenin-Girard, Le Campaniforme d'Alle, Noir Bois (Jura, Suisse). Cahier d'archéologie jurassienne 7 (Porrentury 1997).

\section{Primas 1972}

M. Primas, (1972), Funde der späten Bronzezeit aus den Eisenzeitnekropolen des Kantons Tessin, Zeitschrift für schweizerische Archäologie und Kunstgeschichte 29, 5-18.

\section{Primas 1979}

M. Primas (1979), Archäologische Untersuchungen in Tamins GR. Die spätneolithische Station "Crestis", Jahrbuch der Schweizerischen Gesellschaft für Urund Frühgeschichte 62, 13-27.

\section{Primas 1998}

M. Primas, Der bronzezeitliche Landausbau in den Alpen, in: B. H. Hänsel (Hrsg.), Mensch und Umwelt in der Bronzezeit Europas. Die Bronzezeit: das erste goldene Zeitalter Europas (Kiel 1998) 355-365.

\section{Primas 2004}

M. Primas, Das Bronzezeitliche Fundmaterial, in: $M$. Primas / P. Della Casa / Z. E. Jochum / R. Huber (Hrsg.), Wartau. Ur- und frühgeschichtliche Siedlungen und Brandopferplatz im Alpenrheintal (Kanton St. Gallen, Schweiz). Bronzezeit, Kupferzeit, Mesolitikum, Universitätsforschungen zur prähistorischen Archäologie 108, 2 (Zürich 2004) 31-72.

\section{Primas 2013}

M. Primas, Settlement and interregional connections in the Central and Eastern Alps, in: H. Meller / F. Bertemes / H.-R. Bork / R. Risch (Hrsg.), 1600 - Kultureller Umbruch im Schatten des Thera-Ausbruchs? 4. Mitteldeutscher Archäologentag vom 14. bis 16. Oktober 2011 in Halle (Saale), Tagungen des Landesmuseums für Vorgeschichte Halle 9 (Halle 2013) 435-442.

\section{Rachoud-Schneider et al. 1998}

A.-M. Rachoud-Schneider/S. Jacomet/H. Zollner, 2.2.3. Vegetationsveränderung durch menschlichen Einfluss, Ackerbau, Sammelwirtschaft und Grünlandwirtschaft. In: S./Hochuli/U. Niffeler/V. Rychner (Hrsg.), SPM III. Bronzezeit (Basel 1998), 151-167.

\section{Rageth 1976}

J. Rageth (1976), Die bronzezeitliche Siedlung auf dem Padnal bei Savognin (Oberhalbstein GR). Grabungen 1971 und 1972, Jahrbuch der Schweizerischen Gesellschaft für Ur- und Frühgeschichte $59,123-179$.

\section{Rageth 1986}

J. Rageth (1986), Die wichtigsten Resultate der Ausgrabungen in der bronzezeitlichen Siedlung auf dem Padnal bei Savognin (Oberhalbstein GR), Jahrbuch der Schweizerischen Gesellschaft für Urund Frühgeschichte 69, 63-103.

\section{Rageth 1992}

J. Rageth, Mesocco - Tec Nev, der älteste Siedlungsplatz Graubündens, in: Archäologie in Graubünden. Funde und Befunde (Chur 1992) 22-25.

\section{Rageth 1998}

J. Rageth, Die spätbronzezeitlichen Siedlungsreste von Chur - Areal Sennhof und Karlihof, in: G. Ciuletti / F. Marzatico (Hrsg.), Die Räter, Archeoalp - Archeologia delle Alpi 5/1 (Trento 1998) 61-87.

\section{Rageth 2000}

J. Rageth, Die Urgeschichte, in: Handbuch der Bündner Geschichte 1. Frühzeit bis Mittelalter (2000) 15-60.

\section{Reitmaier 2010}

T. Reitmaier, Auf der Hut - Methodische Überlegungen zur prähistorischen Alpwirtschaft in der Schweiz. In: F. Mandl/H. Stadler (Ed.), Archäologie in den Alpen. Alltag und Kult (Innsbruck 2010), 219-238.

\section{Reitmaier 2012}

T. Reitmaier, 1411v. Chr. - Die Mittelbronzezeitliche Quellfassung von St. Moritz, in: Waffen für die Götter. Krieger, Trophäen, Heiligtümer. Katalog zur Ausstellung (Innsbruck 2012a) 111-113.

T. Reitmaier, Letzte Jäger, erste Hirten. Alpine Archäologie in der Silvretta 2007-2012, in: T. Reitmaier (Hrsg.), Letzte Jäger, erste Hirten. Alpine Archäologie in der Silvretta, Archäologie in GraubündenSonderheft 1 (Chur 2012b) 9-65.

\section{Reitmaier/Della Casa 2012}

T. Reitmaier/P. Della Casa (2010), Strukturwandel und Metallboom, Archäologie Schweiz 33/2, 30-25.

\section{Rigert 2005}

E. Rigert (2005), Archäologie im St. Galler Rheintal. Inventarisierung von Fundstellen im Rahmen eines Lotteriefondsprojektes, Werdenberger Jahrbuch $18,238-254$.

\section{Rigert et al. 2005}

E. Rigert/l. Ebneter/R. Ebersbach (2005), Die Epi-Rössener Siedlung von Sevelen SG Pfäfersbüel, Jahrbuch der Schweizerischen Gesellschaft für Ur- und Frühgeschichte 88, 41-86. 


\section{Röder 2016}

B. Röder, Alles schön vertraut hier. Wer wohnte im Pfahlbau? In: Archäologisches Landesmuseum Baden-Württemberg/Landesamt für Denkmalpflege im Regierungspräsidium Stuttgrad (Hrsg.), 4000 Jahre Pfahlbauten (Ostfildern 2016), 137-142.

\section{Röpke 2006}

A. Röpke, Der Wandel von der Natur- zur Kulturlandschaft im Hochtal von St. Antönien (Schweiz). Ein Methodenverbund aus Palynologie, Bodenkunde und Dendroökologie (Frankfurt am Main 2006).

\section{Röpke 2012}

A. Röpke (2012), Past Land-Use and Fire Management in the Montafon Valley (Northern Alps): An Integrated Palaeoenvironmental Approach, eTopoi Journal of Ancient Studies 3, 1007-1037.

\section{Rychner 1998}

V. Rychner, 1.1. Einleitung. In: S./Hochuli/U. Niffeler/V. Rychner (Hrsg.), SPM III. Bronzezeit (Basel 1998), 13-17.

\section{Rychner et al. 1998}

V. Rychner/S. Bolliger Schreyer/R. Carazzetti/M. David-Elbiali/A. Hafner/S. Hochuli/R. Janke/J. Rageth/M. Seifert, 1.5. Geschichte und Kulturen der Bronzezeit in der Schweiz. In: S./Hochuli/U. Niffeler/V. Rychner (Hrsg.), SPM III. Bronzezeit (Basel 1998), 103-134.

\section{Schibler 2008}

J. Schibler, Die wirtschaftliche Bedeutung der Viehzucht während des 3. Jahrtausend v. Chr. Aufgrund der Tierknochenfunde der Fundstellen im Schweizer Alpenvorland. In: W. Dörfler/J. Müller (Hrsg.), Umwelt, Wirtschaft Siedlungen im dritten vorchristlichen Jahrtausend Mitteleuropas und Südskandinaviens. Offa Bücher 84 (Neumünster 2008), 379-391.

\section{Schibler/Jacomet 2010}

J. Schibler/S. Jacomet, Short Climatic Fluctuations and Their Impact on Human Economies and Societies. The Potential of the Neolithic Lake Shore Settlements in the Alpine Foreland. Environmental Archaeology 15/2, 2010, 173-182.

\section{Schibler/Studer 1998}

J. Schibler/J. Studler, 2.3. Haustierhaltung und Jagd während der Bronzezeit der Schweiz. In: S./Hochuli/U. Niffeler/V. Rychner (Hrsg.), SPM III. Bronzezeit (Basel 1998), 171-191.

\section{Schibler et al. 1997}

J. Schibler/H. Hüster-Plogmann/S. Jacomet/C. Brombacher/E. Gross-Klee/A. Rast-Eicher, Ökonomie und Ökologie neolithischer und bronzezeitlicher Ufersiedlungen am Zürichsee. Ergebnisse der Ausgrabungen Mozartstrasse, Kanalisationssanierung Seefeld, AKAD/Pressehaus und Mythenschloss in Zürich. Monographien der Kantonsarchäologie Zürich 20 (Zürich 1997).

\section{Seifert 1997}

M. Seifert (1997), Domat/Ems, Crestas, Ur- und frühgeschichtliche Siedlungsreste (En Streia Nr. 4, Via Nova Nr. 87, Parzelle 545, Erschliessungsstrasse Crestas, Parzelle 535), Jahresberichte des Archäo- logischen Dienstes Graubünden und der Denkmalpflege Graubünden, 28-35.

\section{Seifert 2000}

M. Seifert (2000), Vor 3466 Jahren erbaut! Die Quellfassung von St. Moritz, Archäologie der Schweiz 23, 63-75.

\section{Seifert 2004}

M. Seifert, Schellenberg-Borscht. Ein prähistorischer Siedlungsplatz im Fürstentum Liechtenstein. Die Funde aus Hirschgeweih, Knochen, Felsgestein, Silex und Bergkristall, IV (Triesen 2004).

\section{Seifert 2008}

M. Seifert (2008), Das Alpenrheintal: drei Länder, ein Kulturraum. Im Kontakt mit Nord und Süd, Archäologie Schweiz 31/2, 21-30.

\section{Seifert 2012}

M. Seifert, Zizers GR-Friedau - mittelneolithische Siedlung mit Hinkelsteinkeramik im Bündner Alpenrheintal (Schweiz), in: A. Boschetti-Maradi / A. De Capitani / S. Hochuli / U. Niffeler (Hrsg.), Form, Zeit und Raum. Grundlagen für eine Geschichte aus dem Boden. Festschrift für Werner E. Stöckli zu seinem 65. Geburtstag, Antiqua 50 (Basel 2012) 79-94.

\section{Seifert 2013}

M. Seifert (2013), Den Jägern auf der Spur - Mittelsteinzeit bei Tamins, Crestis, Archäologie Graubünden 1, 123-127.

\section{Spindler 1973}

K. Spindler (1973), Die frühbronzezeitlichen Flügelnadeln, Jahrbuch der Schweizerischen Gesellschaft für Ur- und Frühgeschichte 57, 17-83.

\section{Stauffer 1976}

L. Stauffer, Die Siedlungsreste auf der Mottata bei Ramosch (im Unterengadin), Lizentiatsarbeit Uni Zürich, 1 (1976).

\section{Stauffer-Isenring 1983}

L. Stauffer-Isenring, Die Siedlungsreste von ScuolMunt Baselgia (Unterengadin GR). Ein Beitrag zur inneralpinen Bronze- und Eisenzeit, ANTIQUA 9 (Basel 1983).

\section{Stehrenberger 2012}

T. Stehrenberger (2012), Triesen, Fürst-Johann-Strasse 40. Das Doppelgrab aus Triesen im regionalen und überregionalen Umfeld, Denkmalpflege und Archäologie für Fürstentum Liechtenstein. Fund und Forschungsberichte 2011, 144-149.

\section{Steinhauser-Zimmermann 1989}

R.A. Steinhauser-Zimmermann, Der Montlingerberg im Kanton St. Gallen (Schweiz). Funde und Grabungen von 1898 bis 1960 (Buchs 1989).

\section{Stöckli 2009}

W.E. Stöckli, Chronologie und Regionalität des jüngeren Neolithikums (4300-2400 v. Chr.) im Schweizer Mittelland, Süddeutschland und Ostfrankreich aufgrund der Keramik und der absoluten Datierungen, ausgehend von den Forschungen in den Feuchtbodensiedlungen der Schweiz. Antiqua 45 (Basel 2009). 


\section{Stöckli 2016}

W.E. Stöckli, Urgeschichte der Schweiz im Überblick (15 000 v.Chr.-Christi Geburt). Die Konstruktion einer Urgeschichte, ANTIQUA 54 (Basel 2016).

\section{Thomas 1974}

K.V. Thomas, Die urgeschichtliche Höhensiedlung Mutta bei Fellers, Kt. Graubünden. Inaugural-Dissertation. (1974).

\section{Tinner et al 2007}

W. Tinner, E.H. Nielsen, A. Lotter, Mesolithic agriculture in Switzerland? A critical review of the evidence. In: Quaternary Science Reviews, Volume 26, Issues 9-10, May 2007, Pages 1416-1431.

\section{Vogt 1945}

E. Vogt (1945), Die Ausgrabungen auf dem Lutzengüetle bei Eschen, Jahrbuch des Historischen Vereins für das Fürstentum Liechtenstein 45, 151-169.

\section{Von Uslar 1991}

R. Von Uslar, Vorgeschichtliche Fundkarten der Alpen, Römisch-germanische Forschungen 48 (Mainz 1991).

\section{Vonbank 1966}

E. Vonbank, Frühbronzezeitliche Siedlungsfunde im Voralberger Rheintal, in: R. Degen / W. Drack / R. Wyss (Hrsg.), Festschrift Emil Vogt, Beiträge zur Prähistorie und Archäologie der Schweiz, Helvetia Antiqua (Zürich 1966) 55-58.

\section{Weichhart 2003}

P. Weichhart, Gesellschaftliche Metabolismus und Action Settings. Die Verknüpfung von Sach- und Sozialstrukturen im alltagsweltlichen Handeln. In: P. Meusburger/T. Schwan (ed.), Humanökologie. Ansätze zur Überwindung der Natur-Kultur-Dichotomie. Erdkundliches Wissen 135 (Eurasburg 2003), 15-44.

Wirtz/Lemmen 2003

K. W. Wirtz/C. Lemmen, A Global Dynamic Model for the Neolithic Transition. Climate Change 59, 2003, 333-367.

Würfel et al. 2010

F. Würfel/A. Röpke/J. Lutz/R. Krause (2010), Prähistorische Siedlungsdynamik und Landschaft in einer inneralpinen Siedlungskammer - archäologische, geoarchäologische, archäometallurgische und archäobotanische Untersuchungen im Montafon in Vorarlberg (Österreich), Archäologisches Korrespondenzblatt 40, 503-523.

\section{Wyss 1982}

R. Wyss (1982), Die Höhensiedlung Motta Vallac im Oberhalbstein (Salouf GR), Archäologie der Schweiz 5, 76-82.

Wyss 1996

R. Wyss, Funde von Pässen, Höhen, aus Quellen und Gewässern der Zentral- und Westalpen, in: P. Schauer (Hrsg.), Archäologische Forschungen zum Kultgeschehen in der jüngeren Bronzezeit und frühen Eisenzeit Alteuropas. Ergebnisse eines Kolloquiums in Regensburg, 4.-7. Oktober 1993, Regensburger Beiträge zur prähistorischen Archäologie 2 (Regensburg 1996) 417-428.

\section{Wyss 2002}

R. Wyss, Die bronzezeitliche Hügelsiedlung Cresta bei Cazis. Ergebnisse der Grabungen von 1943 bis 1970, Archaeologische Forschungen, 1 (Zürich 2002).

Zimmermann 2014

A. Zimmermann, Landschaftsarchäologie. In: D. Mölders/S. Wolfram (Ed.), Schlüsselbegriffe der Prähistorischen Archäologie. Tübinger Archäologische Taschenbücher 11 (Münster 2014), 161-166.

\section{Zürcher 1982}

A. Zürcher, Urgeschichtliche Fundstellen Graubündens, Schriftenreihe des Rätischen Museums Chur 27 (Chur 1982). 
Хафнер А., Брюннер М., Лаабс Д.

\section{Археологія альпійського простору. Дослідження передгір'їв, долинних систем та високогірних ландшафтів Альп}

В даній статті наводяться приклади ландшафтних археологічних досліджень в альпійському регіональному контексті. Як навколо, так і в самих Європейських Альпах ландшафти відзначаються великою різноманітністю. Найбільш істотні ландшафтні відмінності спостерігаються на висотах, що мають відмітки від 400 до 3000 і більше метрів над рівнем моря. Основними топографічними ознаками регіону являються горбисті альпійські передгір'я, широкі внутрішні долини, що заходять далеко в самі Альпи та високогірні зони, які починаються вище лінії деревної рослинності. В статті наводяться приклади, що тематично охоплюють пам'ятки від озерних та болотяних поселень на палях у передгірних районах, поховань та поселень у внутрішньоальпійських височинах та річкових терасах до короткочасних таборів та пам'яток на високогірних перевалах. Археологічні свідчення вказують, що поселенська активність починає спостерігатись в усіх регіонах від початку 5-го тисячоліття до н.е. Палеоекологічні дані з передгірних територій можуть віддалити цю межу навіть до середини 6-го тисячоліття до н.е. Автори допускають високий ступінь мобільності між цими регіонами. Якщо озерні та болотяні поселення добре відомі та докладно вивчені вченими, дослідження альпійських високогірних пам'яток почалось тільки два десятиліття тому. Альпи та оточуючі передгірські ландшафти являються яскравим полем для археологічних досліджень, особливо при вивченні ранньоземлеробських культур. Незважаючи на те, що постійні дослідження дають можливість кращого розуміння процесів проникнення перших аграрних суспільств з передальпійських низин в високогірні зони, ми все ще далекі від остаточного розуміння загальної картини. Довготривала еволюція поселенської діяльності, що відбувалась у передгірних районах та у частині внутрішньо альпійських долин перетворила незаймані ландшафти у міські простори з одного боку, 3 маленькими внутрішньо-альпійськими долинами та високогірними районами, де поширились стійкі форми землекористування з іншого, що відобразилось на характері культурного ландшафту Альп. 


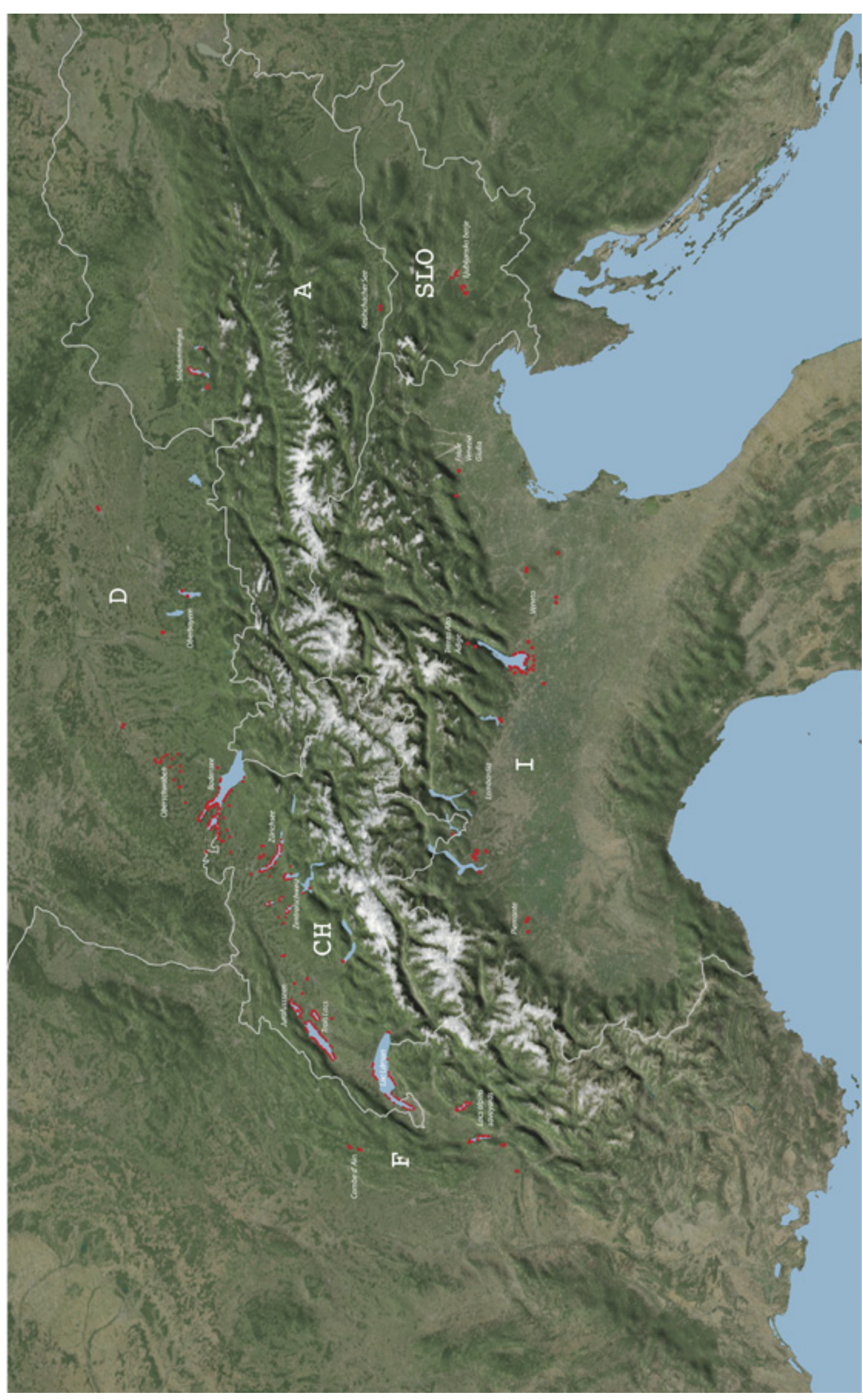

هั่

$\varepsilon$ 후

(

음

응

匀

춘

음

음

药

突

这

苯

区

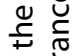

은

ن

은

落

这

हो

吾六

ํํㅇ

ำ.

离

$\sum_{\substack{0 \\ d}}^{3} \frac{\pi}{\frac{\pi}{\pi}}$

产要

은

से

엉

oํ

㟧

도

స

․ㅗ․

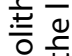

峁

응 항

언

$\simeq$

일

क्ष

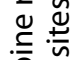

운듬

둥

응

है

흠

$\cong$

政

웅

.

焉

둥

ํㅡㅇㅇㅇ

운

ป 든

잉

ํㅜㅇ

语 

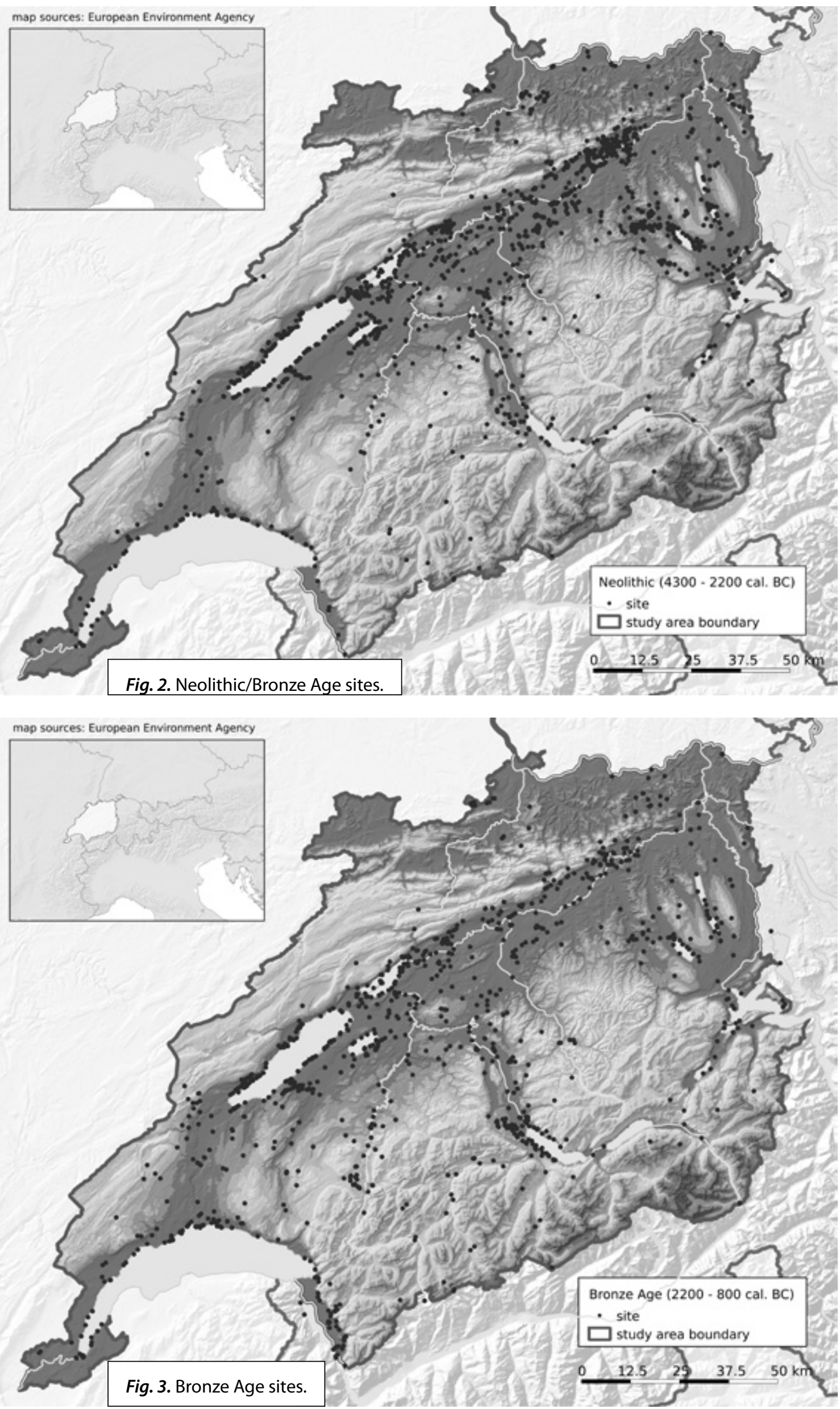


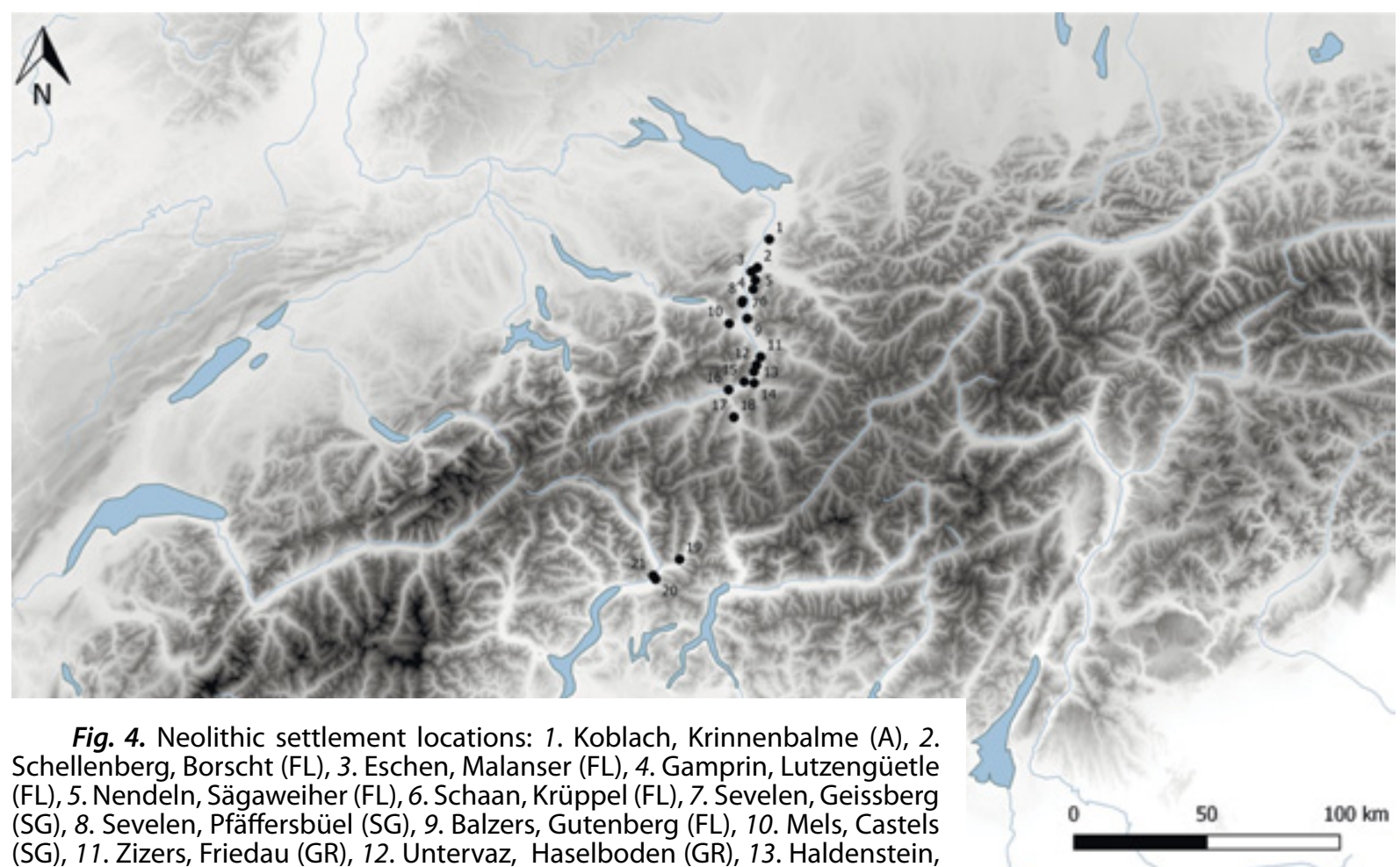
(SG), 11. Zizers, Friedau (GR), 12. Untervaz, Haselboden (GR), 13. Haldenstein, Lichtenstein (GR), 14. Chur, Welschdörfli (GR), 15. Felsberg, Obere und Untere Tgilväderlishöhle (GR), 16. Tamins, Crestis (GR), 17. Cazis, Petrushügel (GR), 18. Mesocco, Tec Nev/S. Maria del Castello (GR), 19. Castaneda, Pian del Remit (GR), 20. Bellinzona, Castel Grande (TI), 21. Bellinzona, Carasso, Lusanico ( $\mathrm{TI})$.

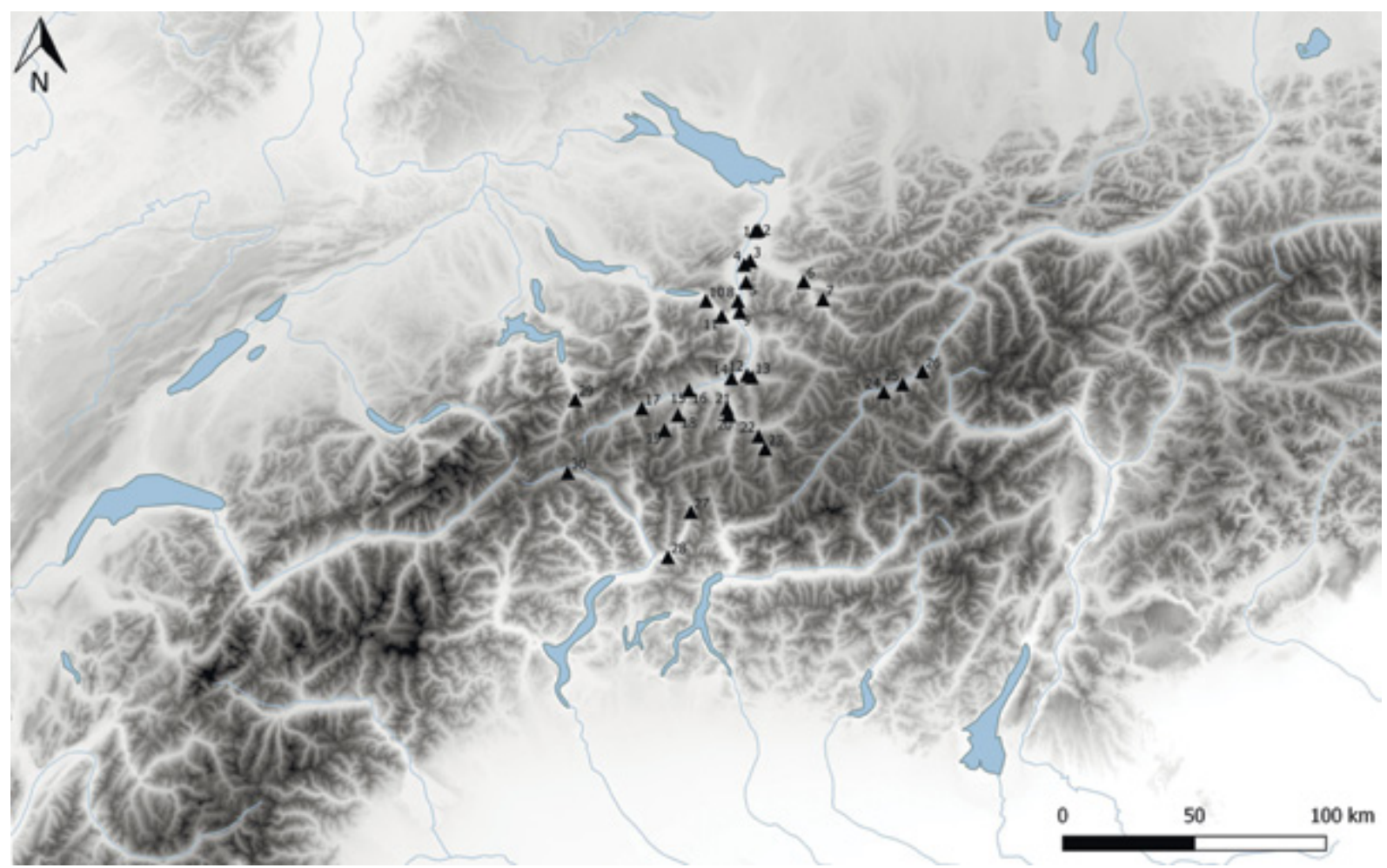

Fig. 5. The main Bronze Age settlement locations : 1. Oberriet, Montlingerberg (SG), 2. Koblach, Kadel (A), 3. Schellenberg, Borscht ( $F L)$, 4. Eschen, Malanser ( $F L)$, 5. Schaan, Krüppel (FL), 6. Bludenz, Kleiner Exerzierplatz (A), 7. Friaga Wald, Bartholomäberg (A), 8. Wartau, Ochsenberg (SG), 9. Balzers, Runda Büchel, Gutenberg (FL), 10. Flums, Gräpplang (SG), 11. Mels, Castels (SG), 12. Chur, Areal Ackermann und Sennhof/Karlihof (GR), 13. Maladers, Tummihügel (GR), 14. Domat /Ems, Crestas (GR), 15. Falera/Fellers, Muota (GR), 16. Waltensburg, Jörgenstein (GR), 17. Trun, Grepault (GR), 18. Vella/Villa, Pleiv (GR), 19. Lumbrein/Surin, Crestaulta (GR), 20. Cazis, Cresta (GR), 21. Cazis, Petrushügel (GR), 22. Salouf, Motta Vallac (GR), 23. Savognin, Padnal (GR), 24. Ardez, Suotchastè (GR), 25. Scuol, Munt Baselgia Kirchhügel (GR), 26. Ramosch, Mottata (GR), 27. Mesocco, Tec Nev/S. Maria del Castello (GR), 28. Roveredo, Valasc (GR), 29. Amsteg, Flüeli (UR), 30. Airolo, Madrano (TI). 


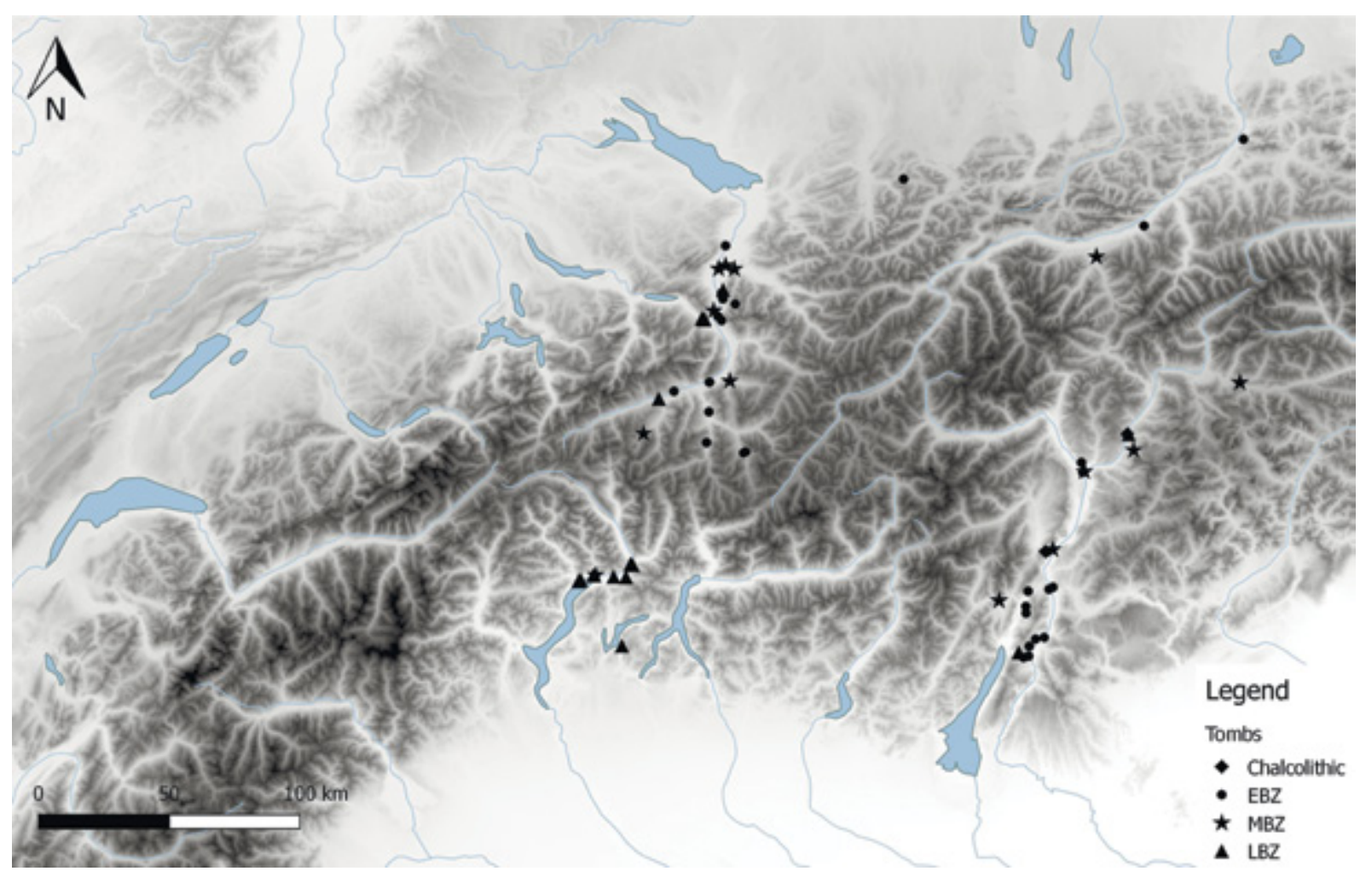

Fig. 6. Bronze Age graves in the central-Alpine region.

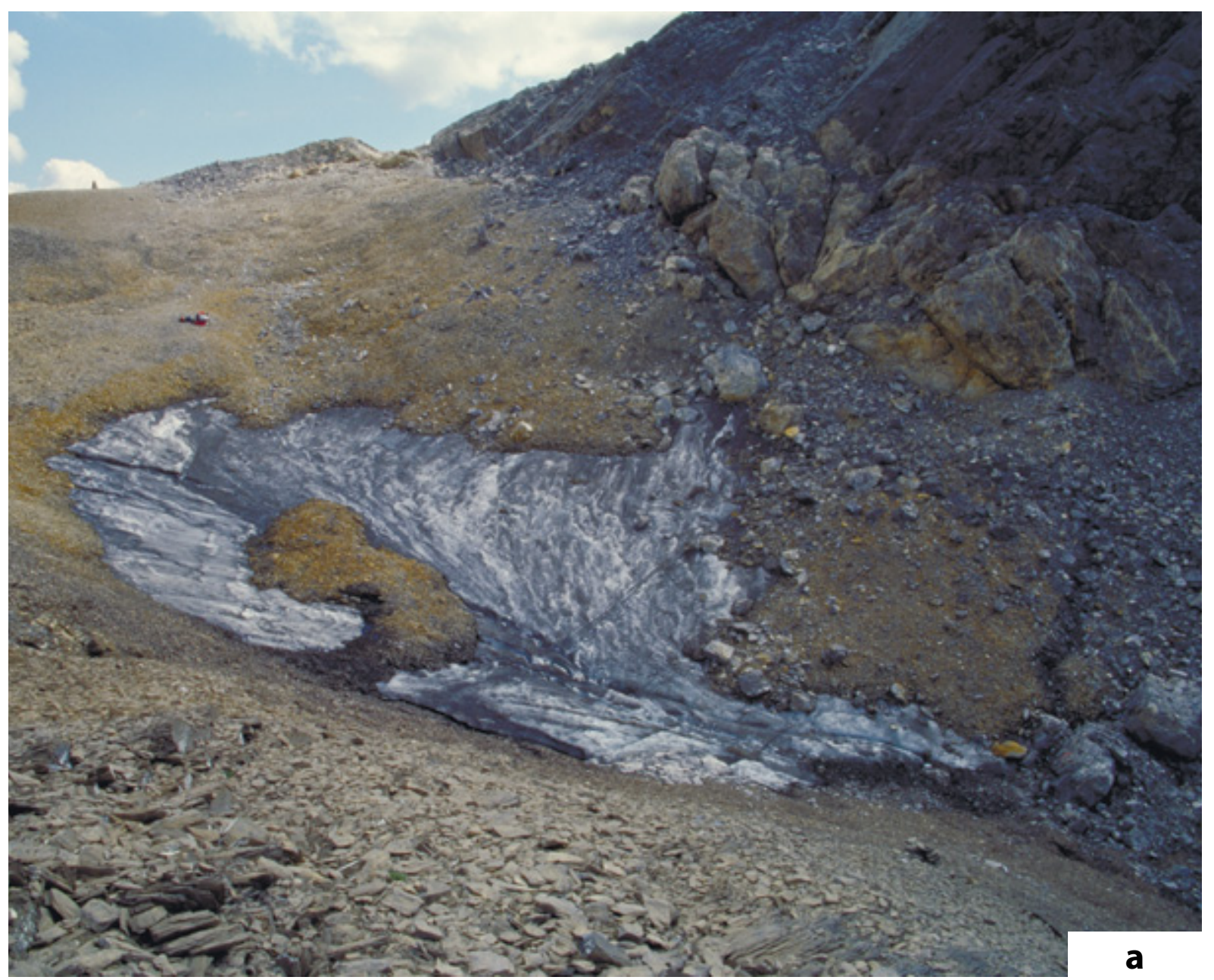

Fig. 7a. Schnidejoch, western Bernese Alps, $2756 \mathrm{~m}$ a.s.l. General overview of the pass. 


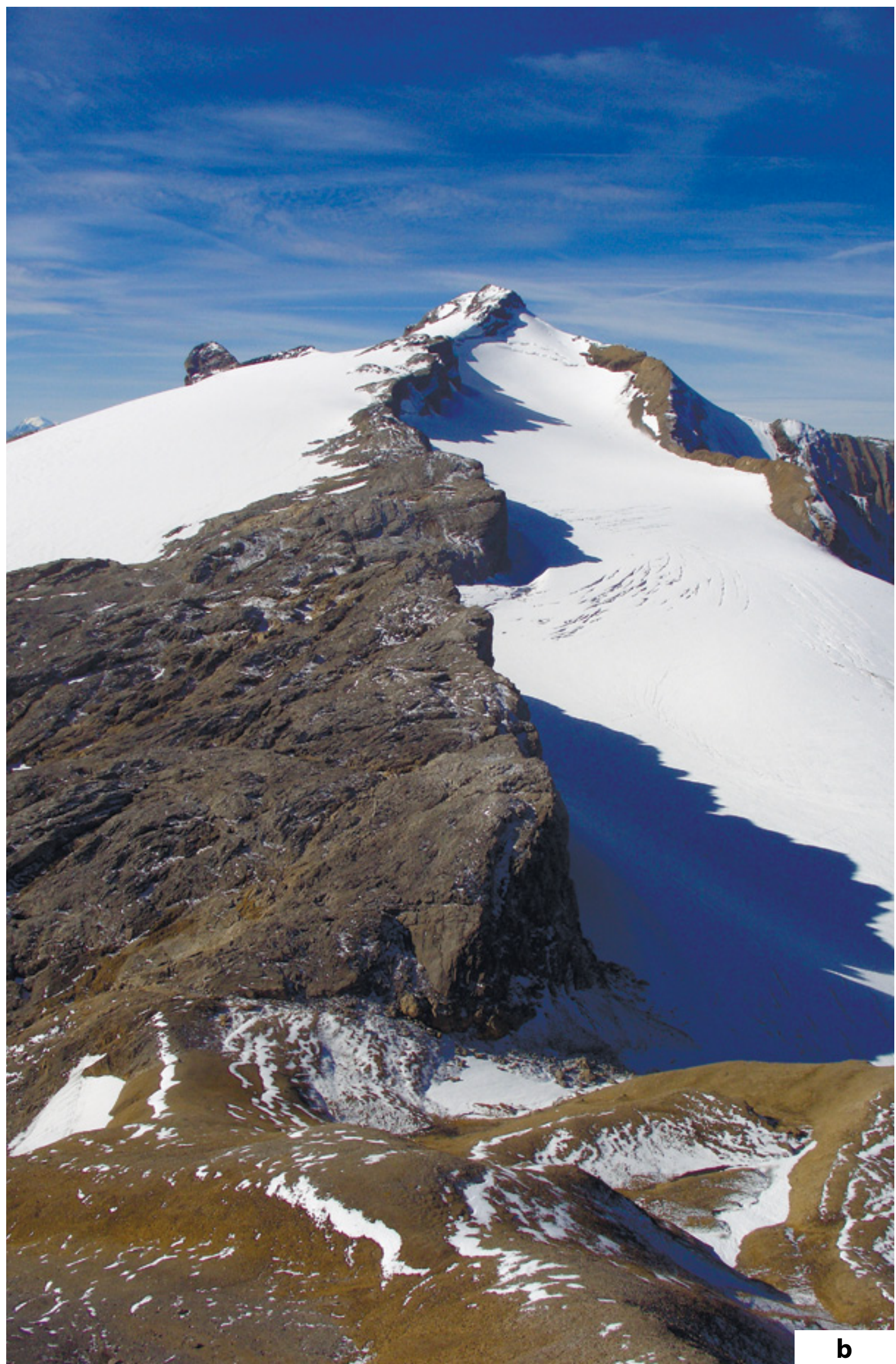

Fig. 7b. Schnidejoch, western Bernese Alps, $2756 \mathrm{~m}$ a.s.I. General overview of the pass. 
ETH-39616/UZ-5784 ETH-29572/UZ-5172.2 ETH-29572/UZ-5172.1 ETH-34940/UZ-5607 ETH-38974/UZ-5765 ETH-32033/UZ-5334 ETH-32032/UZ-5333 ETH-37758/UZ-5707 ETH-39619/UZ-5787 ETH-32036/UZ-5337 ETH-30082/UZ-5188 ETH-31146/UZ-5257 Poz-33732

ETH-34939/UZ-5605 ETH-32038/UZ-5339 ETH-34936/UZ-5602 ETH-32035/UZ-5336 ETH-34934/UZ-5600 Poz-27148

ETH-31147/UZ-5258 Poz-27147

ETH-29574/UZ-5174 ETH-31148/UZ-5259 ETH-29576/UZ-5176 ETH-30938/UZ-5248 ETH-32037/UZ-5339 ETH-31141/UZ-5252 ETH-39617/UZ-5785 ETH-32034/UZ-5335 ETH-31142/UZ-5253 ETH-38875/UZ-5766 ETH-37757/UZ-5706 ETH-34939/UZ-5604 ETH-34937/UZ-5603 ETH-29573/UZ-5173 ETH-32044/UZ-5345 ETH-29693/UZ-5180 ETH-32039/UZ-5340 ETH-32040/UZ-5341 ETH-30937/UZ-5247 ETH-28346/UZ-5061 ETH-31144/UZ-5255 ETH-31883/UZ-5332 ETH-37925/UZ-5710 ETH-39614/UZ-5782 ETH-31143/UZ-5254 ETH-35570/UZ-5635 ETH-31145/UZ-5256 ETH-37926/UZ-5711 ETH-40158/UZ-5824 ETH-40157/UZ-5823 ETH-32042/UZ-5343 ETH-40159/UZ-5825 ETH-29692/UZ-5179 ETH-37755/UZ-5704 ETH-39615/UZ-5783 ETH-32041/UZ-5342 ETH-40156/UZ-5822 ETH-40155/UZ-5821 ETH-29575/UZ-5175 ETH-41750/UZ-5941 ETH-41749/UZ-5940 ETH-37760/UZ-5709 ETH-39618/UZ-5786 ETH-35569/UZ-5606 ETH-32499/UZ-5344 ETH-32043/UZ-5344 ETH-44117/UZ-5985 ETH-37756/UZ-5705 ETH-38877/UZ-5768 ETH-37759/UZ-5708 ETH-39475/UZ-5781 ETH-39474/UZ-5780 ETH-37754/UZ-5703

Fig. 8. Schnidejoch, western Bernese Alps, $2756 \mathrm{~m}$ a.s.l. Radiocarbon dates obtained from organic finds from the melting ice field on the northern side of the pass. 


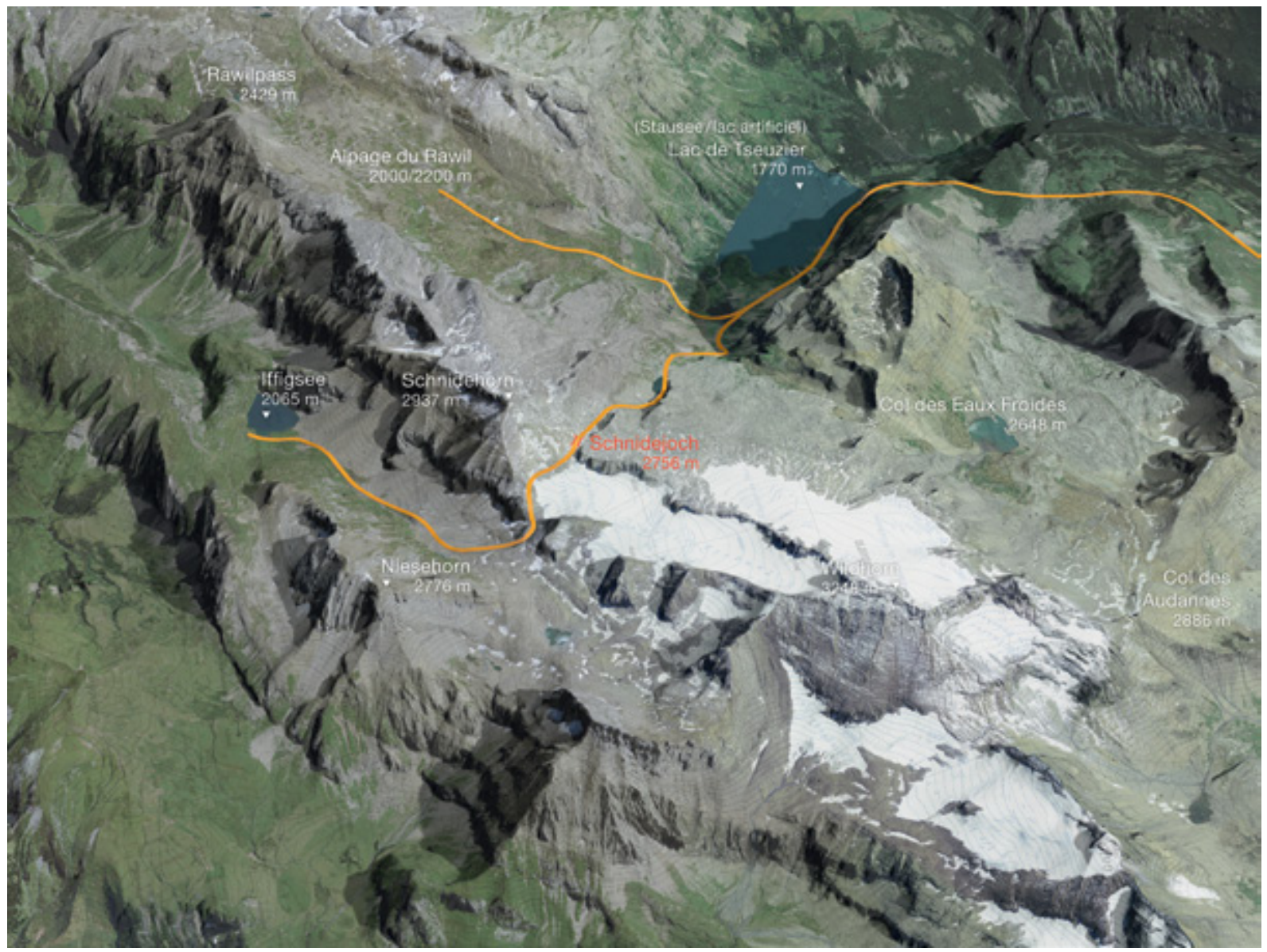

Fig. 9. Schnidejoch, western Bernese Alps, $2756 \mathrm{~m}$ a.s.l. Land-use model for transhumance with small ruminants from the southern Rhône Valley via the Schnidejoch Pass to Alpine pastures. 